\title{
Spatiotemporal variability and long-term trends of ocean acidification in the California Current System
}

\author{
C. Hauri ${ }^{1,6}$, N. Gruber ${ }^{1}$, M. Vogt $^{1}$, S. C. Doney ${ }^{2}$, R. A. Feely ${ }^{3}$, Z. Lachkar ${ }^{1}$, A. Leinweber ${ }^{4}$, A. M. P. McDonnell ${ }^{1,6}$, \\ M. Munnich ${ }^{1}$, and G.-K. Plattner ${ }^{1,5}$ \\ ${ }^{1}$ Environmental Physics, Institute of Biogeochemistry and Pollutant Dynamics, ETH Zurich, Zurich, Switzerland \\ ${ }^{2}$ Dept. of Marine Chemistry and Geochemistry, Woods Hole Oceanographic Institution, Woods Hole, MA, USA \\ ${ }^{3}$ Pacific Marine Environmental Laboratory/National Oceanic and Atmospheric Administration, Seattle, WA, USA \\ ${ }^{4}$ Institute of Geophysics and Planetary Physics, University of California, Los Angeles, CA, USA \\ ${ }^{5}$ Climate and Environmental Physics Group, Physics Institute, University of Bern, Bern, Switzerland \\ ${ }^{6}$ now at: School of Fisheries and Ocean Sciences, University of Alaska Fairbanks, Fairbanks, AK, USA
}

Correspondence to: C. Hauri (chauri@alaska.edu)

Received: 6 July 2012 - Published in Biogeosciences Discuss.: 6 August 2012

Revised: 4 December 2012 - Accepted: 7 December 2012 - Published: 14 January 2013

\begin{abstract}
Due to seasonal upwelling, the upper ocean waters of the California Current System (CCS) have a naturally low $\mathrm{pH}$ and aragonite saturation state $\left(\Omega_{\mathrm{arag}}\right)$, making this region particularly prone to the effects of ocean acidification. Here, we use the Regional Oceanic Modeling System (ROMS) to conduct preindustrial and transient (1995-2050) simulations of ocean biogeochemistry in the CCS. The transient simulations were forced with increasing atmospheric $p \mathrm{CO}_{2}$ and increasing oceanic dissolved inorganic carbon concentrations at the lateral boundaries, as projected by the NCAR CSM 1.4 model for the IPCC SRES A2 scenario. Our results show a large seasonal variability in $\mathrm{pH}$ (range of $\sim 0.14$ ) and $\Omega_{\mathrm{arag}}$ $(\sim 0.2)$ for the nearshore areas ( $50 \mathrm{~km}$ from shore). This variability is created by the interplay of physical and biogeochemical processes. Despite this large variability, we find that present-day $\mathrm{pH}$ and $\Omega_{\text {arag }}$ have already moved outside of their simulated preindustrial variability envelopes (defined by \pm 1 temporal standard deviation) due to the rapidly increasing concentrations of atmospheric $\mathrm{CO}_{2}$. The nearshore surface $\mathrm{pH}$ of the northern and central CCS are simulated to move outside of their present-day variability envelopes by the mid-2040s and late 2030s, respectively. This transition may occur even earlier for nearshore surface $\Omega_{\text {arag}}$, which is projected to depart from its present-day variability envelope by the early- to mid-2030s. The aragonite saturation horizon of the central CCS is projected to shoal into the upper $75 \mathrm{~m}$ within the next $25 \mathrm{yr}$, causing near-permanent undersatura-
\end{abstract}

tion in subsurface waters. Due to the model's overestimation of $\Omega_{\text {arag }}$, this transition may occur even earlier than simulated by the model. Overall, our study shows that the CCS joins the Arctic and Southern oceans as one of only a few known ocean regions presently approaching the dual threshold of widespread and near-permanent undersaturation with respect to aragonite and a departure from its variability envelope. In these regions, organisms may be forced to rapidly adjust to conditions that are both inherently chemically challenging and also substantially different from past conditions.

\section{Introduction}

Since the onset of the industrial era, the oceans have absorbed about one-third of the anthropogenically emitted carbon dioxide (Sabine et al., 2004). The uptake of anthropogenic $\mathrm{CO}_{2}$ by the oceans has already reduced the global surface ocean pH by about 0.1 units (Feely et al., 2004) and it is projected to decrease another 0.3 to $0.4 \mathrm{pH}$ units by the end of this century under the IPCC 1992 (IS92a) scenario (788 ppm in 2100, Orr et al., 2005). This chemical change, known as ocean acidification, also leads to a decline in the saturation state $(\Omega)$ of seawater with respect to calcium carbonate minerals, such as calcite or the less stable form aragonite. While this altered carbon chemistry and its effects on marine ecosystems are an ongoing subject of intensive

Published by Copernicus Publications on behalf of the European Geosciences Union. 
scientific research (Doney et al., 2012), many (although not all) results have demonstrated that these changes can have deleterious effects on marine-calcifying invertebrates such as corals, coralline algae, oyster larvae and pteropods (Orr et al., 2005; Kleypas et al., 2006; Martin and Gattuso, 2009).

The California Current System (CCS) has a naturally low $\mathrm{pH}$ and aragonite saturation state $\left(\Omega_{\mathrm{arag}}\right)$, making it particularly prone to the effects of ocean acidification (Feely et al., 2008; Gruber et al., 2012). Seasonal upwelling is induced by equatorward winds in early spring. The upwelling brings cold subsurface water, rich in nutrients and dissolved inorganic carbon (DIC), up to the surface. The high DIC content of the upwelled waters endows them with a low $\mathrm{pH}$ and $\Omega_{\text {arag }}$. Once close to the surface, the nutrient-rich water triggers the onset of phytoplankton blooms that then draw down oceanic $p \mathrm{CO}_{2}$ to levels sometimes below atmospheric $p \mathrm{CO}_{2}$ (Hales et al., 2005), causing an increase in surface water $\mathrm{pH}$ and $\Omega_{\text {arag. }}$. Conversely, remineralization processes of sinking organic matter counteract the effects of production by lowering $\mathrm{pH}$ and $\Omega_{\text {arag. }}$. Physical circulation can affect the duration and magnitude of these biological processes and therefore plays an important role in controlling the evolution and spatial pattern of $\mathrm{pH}$ and $\Omega_{\text {arag }}$.

These physical and biological features create large spatial and temporal variability in $\mathrm{pH}$ and $\Omega_{\text {arag }}$ in the CCS (Feely et al., 2008; Juranek et al., 2009; Alin et al., 2012). North of Point Conception $\left(34.5^{\circ} \mathrm{N}\right)$, a combination of strong seasonal upwelling events and remineralization trigger a $\mathrm{pH}$ drop to 7.65 and $\Omega_{\text {arag }}$ to 0.8 at the surface in some nearshore environments (Feely et al., 2008). Combined with high biological production, a heterogeneous distribution of $\mathrm{pH}$ and $\Omega_{\text {arag }}$ is created. Offshore $\mathrm{pH}$ and $\Omega_{\text {arag }}$ are not directly influenced by upwelling and remain above 8.0 and 2.2 , respectively. Reconstructed $\mathrm{pH}$ and $\Omega_{\mathrm{arag}}$ from temperature $(T)$ and oxygen $\left(\mathrm{O}_{2}\right)$ time series from the central Oregon shelf display a seasonal range of $\Omega_{\text {arag }}$ of $0.8-1.8$ at $30 \mathrm{~m}$ (Juranek et al., 2009), with lowest levels attained during the upwelling season between spring and fall. South of Point Conception, upwelling-favorable winds are weaker, yet more persistent throughout the year (Dorman and Winant, 1995). In contrast to the area north of Point Conception, reconstructed $\mathrm{pH}$ and $\Omega_{\text {arag }}$ from $T$ and $\mathrm{O}_{2}$ time series display the highest levels in summer, due to biological drawdown of $\mathrm{CO}_{2}$ in warm subsurface waters $(30 \mathrm{~m})$. Spatial variability is also highest in summer, most likely driven by an interplay of high productivity and upwelling (Alin et al., 2012). At the Santa Monica Bay Observatory (SMBO at $33^{\circ} 55.9^{\prime} \mathrm{N}$ and $118^{\circ} 42.9^{\prime} \mathrm{W}$ ), surface $\mathrm{pH}$ and $\Omega_{\text {arag }}$ display a large seasonal variability, ranging by \pm 0.08 ( 1 STD) and \pm 0.4 units, respectively (Leinweber and Gruber, 2013).

In the CCS, the aragonite saturation horizon has shoaled 50-100 $\mathrm{m}$ since the preindustrial era (Feely et al., 2008; Hauri et al., 2009; Juranek et al., 2009) and will continue to rise in response to future oceanic uptake of anthropogenic $\mathrm{CO}_{2}$. Simulations forced with increasing atmospheric $p \mathrm{CO}_{2}$
- as projected by the NCAR CSM 1.4 model run under the IPCC SRES A2-scenario (Nakićenović and Swart, 2000) suggest that about $70 \%$ of the euphotic nearshore region of the central US West Coast will become undersaturated with regard to aragonite $(\Omega<1)$ during the upwelling season by 2050. Within the next 20 to $30 \mathrm{yr}$ this "absolute" threshold of aragonite undersaturation will be reached throughout the year in nearly all habitats along the seafloor (Gruber et al., 2012).

Due to the large "natural" variability of $\mathrm{pH}$ and $\Omega_{\mathrm{arag}}$, it is conceivable that the organisms of the CCS are not only well adjusted to low levels of $\mathrm{pH}$ and $\Omega_{\text {arag }}$, but also to a large range of chemical conditions. Therefore, in order to evaluate the impact of ocean acidification, it is also necessary to consider how the chemical conditions evolve in relationship to this "natural"variability. Eventually, the anthropogenic trend of ocean acidification will drive the waters toward levels of $\mathrm{pH}$ and $\Omega_{\text {arag }}$ that are well below those the organism experienced in the preindustrial era. Assuming that the organisms' tolerance for low $\mathrm{pH}$ and $\Omega_{\text {arag }}$ conditions decreases rapidly once it lives below these "natural" levels, we define a "relative" threshold, i.e., by determining how and when future trajectories of $\mathrm{pH}$ and $\Omega_{\text {arag }}$ begin to depart in a significant manner from current and prior conditions. Cooley et al. (2012) and Friedrich et al. (2012) have used global Earth System Models to study this relative threshold. However, their coarsely resolved models are not able to simulate many important local to regional processes, such as coastal upwelling. This in turn leads in these models to an overestimation of $\mathrm{pH}$ and $\Omega_{\text {arag levels, an underestimation of their }}$ temporal and spatial variability, and hence large potential errors in the timing of the crossing of the absolute and relative thresholds.

Here, we use regional model simulations to describe the spatiotemporal variability of $\mathrm{pH}$ and $\Omega_{\text {arag }}$ in the CCS from the Mexican to the Canadian border, and project their future evolution until 2050 using two emissions scenarios. We will investigate whether the CCS, despite its high variability, is projected to approach the combined absolute and relative thresholds of both chemical dissolution of aragonite and a departure from the variability envelopes of $\mathrm{pH}$ and $\Omega_{\text {arag }}$.

\section{Methods}

\subsection{Model setup}

We use a United States West Coast configuration of the threedimensional Regional Oceanic Modeling System (ROMS) (Marchesiello et al., 2003; Shchepetkin and McWilliams, 2005), which simulates flow and mixing of ocean waters at an eddy-resolving horizontal resolution of $5 \mathrm{~km}$. The model covers a 1300-km-wide section along the US West Coast from the US/Canadian border past the US/Mexican border to $29^{\circ} \mathrm{N}$ (Fig. 1). The model grid is defined by horizontal 
curvilinear coordinates and a terrain-following vertical coordinate $(\sigma)$ with 32 depth levels, with enhanced resolution near the surface and nearshore on the shallow shelf (see Gruber et al., 2011; Lachkar and Gruber, 2011, for a detailed description of the model setup).

The biogeochemical model used here is a simple nitrogenbased $\mathrm{NPZD}_{2}$ and is described in detail in Gruber et al. (2006). The analyzed simulations are those presented in Gruber et al. (2012) and use the same biogeochemical parameters as those employed by Lachkar and Gruber (2011). The model considers six pools of nitrogen, i.e., nitrate $\left(\mathrm{NO}_{3}^{-}\right)$and ammonium $\left(\mathrm{NH}_{4}^{+}\right)$, phytoplankton, zooplankton and two types of detritus. The large detritus pool sinks fast $\left(10 \mathrm{mday}^{-1}\right)$ and the smaller one sinks at a slower rate $\left(1 \mathrm{~m} \mathrm{day}^{-1}\right)$. However, the small detritus pool coagulates with a fraction of phytoplankton to form large detritus, which increases its sinking speed.

The carbon component of the model adds three new state variables to the biogeochemical model, i.e., DIC, Alkalinity (Alk) and mineral $\mathrm{CaCO}_{3}$. It is not necessary to add explicit carbon-based state variables to the organic pools, i.e., phytoplankton, zooplankton and the two detrital pools, since they are all assumed to have a fixed C:N stoichiometric ratio of 106 : 16 (Redfield et al., 1963). This also implies that biologically mediated processes with the exception of the biogenic formation of $\mathrm{CaCO}_{3}$ are assumed to have this stoichiometry as well. DIC is modified by gas exchange, $\mathrm{CaCO}_{3}$ precipitation and dissolution, and net community production, which is net primary production minus heterotrophic respiration. Alk is primarily governed by the precipitation and dissolution of $\mathrm{CaCO}_{3}$. But Alk is also changed by the generation of $\mathrm{NO}_{3}^{-}$ through nitrification and its removal by new production. The biogenic $\mathrm{CaCO}_{3}$ formation is tied to net primary production with a fixed production ratio of $7 \%$ (Sarmiento et al., 2002; Jin et al., 2006), i.e., for each mole of organic carbon formed by NPP, $0.07 \mathrm{~mol}$ of $\mathrm{CaCO}_{3}$ is formed. $\mathrm{CaCO}_{3}$ dissolves at a constant dissolution rate of $0.0057 \mathrm{day}^{-1}$ and sinks at a velocity of $20 \mathrm{~m} \mathrm{day}^{-1}$, which is twice the sinking velocity of large detritus. Oceanic $p \mathrm{CO}_{2}$ is calculated from DIC, Alk, $T$ and salinity $(S)$ using the standard OCMIP carbonate chemistry routines ${ }^{1}$. The routines used the carbonic acid dissociation constants of Mehrbach et al. (1973), as refit by Dickson and Millero (1987) and Dickson (1990). The pressure effect on the solubility was taken from Mucci (1983), including the adjustments to the constants recommended by Millero (1995). Gas exchange is parameterized following Wanninkhof (1992), with the gas transfer velocity depending on the square of the wind speed. The reader interested in a more detailed description of the carbon biogeochemistry module is referred to Appendix A.

\footnotetext{
${ }^{1}$ http://ocmip5.ipsl.jussieu.fr/OCMIP/
}

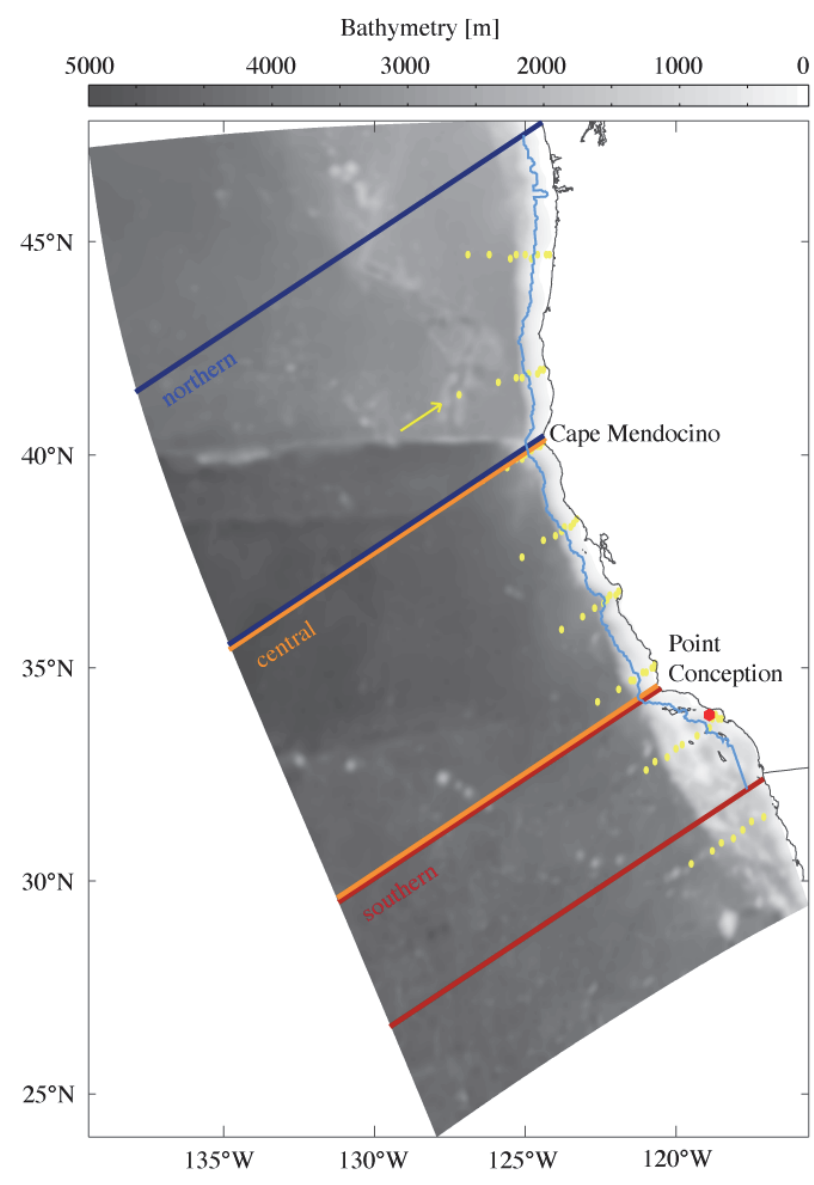

Fig. 1. Map of the domain of the US West Coast configuration of ROMS. The northern subregion is defined by the dark blue box and represents the area between the northern boundary of $47.5^{\circ} \mathrm{N}$ and a southern boundary at Cape Mendocino $\left(40.5^{\circ} \mathrm{N}\right)$. Between Cape Mendocino and Point Conception $\left(34.5^{\circ} \mathrm{N}\right)$ the central subregion is defined by the orange box. The southern subregion extends southward from Point Conception to $32.4^{\circ} \mathrm{N}$. The light blue line defines the study area of $50 \mathrm{~km}$ along the coast. Because of the perpendicular orientation of the regional boundaries, the offshore part of each region's lower boundary lays south of the above mentioned latitudes. The yellow dots indicate the locations used in the model-observational data spatial comparison (see Sect. 3). The arrow is pointed at the transect used for visual comparison. The Santa Monica Bay Observatory Mooring $\left(33^{\circ} 55.9^{\prime} \mathrm{N}\right.$ and $\left.118^{\circ} 42.9^{\prime} \mathrm{W}\right)$ is shown as a red dot.

\subsection{Forcing}

Our analysis is primarily based on a transient simulation for the years 1995 to 2050 (Gruber et al., 2012), with atmospheric $\mathrm{CO}_{2}$ following the SRES A2 emissions scenario (Nakićenović and Swart, 2000). We compare these results with those from a time-slice simulation run under preindustrial conditions (Hauri et al., 2009). For both simulations the physical part of the model remained the same. The model was forced at the surface with monthly climatologies of 
momentum fluxes computed from QuickSCAT-based Scatterometer Climatology of Ocean Winds (SCOW, Risien and Chelton, 2008). The surface heat and freshwater fluxes were derived from the Comprehensive Ocean-Atmosphere Data Set (COADS) data products (da Silva et al., 1994) and applied with surface $T$ and $S$ restoring after Barnier et al. (1995) with a relaxation timescale of three months. To a limited extent, this approach allows implicitly taking into account riverine-driven seasonal variability of $S$ associated with the Columbia River, even though riverine input is not explicitly modeled. The initial and boundary conditions for $T, S$ and nutrients were taken from the World Ocean Atlas 2005 (WOA05) $^{2}$. Monthly means of WOA05 were also used to prescribe $T, S$, and momentum fluxes along the three lateral open boundaries following a radiative scheme (Marchesiello et al., 2003). Initial and boundary conditions for DIC and Alk were taken from the GLobal Ocean Data Analysis Project (GLODAP, Key et al., 2004). A seasonal cycle was introduced in the DIC and Alk boundary conditions using a monthly climatology of $p \mathrm{CO}_{2}$ (Takahashi et al., 2006) and a monthly climatology of surface Alk, calculated using $T$ and $S$ following Lee et al. (2006). These seasonal DIC and Alk variations are assumed to occur throughout the upper $200 \mathrm{~m}$, but are attenuated with depth by scaling them to the vertical profile of the seasonal amplitude of $T$. After a model spin-up of $10 \mathrm{yr}$, the transient simulation was forced with increasing $p \mathrm{CO}_{2}$ from $364 \mathrm{ppm}$ in 1995 to $541 \mathrm{ppm}$ in 2050, and increasing DIC concentrations at the lateral boundaries. These atmospheric and lateral boundary conditions were taken from a simulation of the fully coupled Earth System Model NCAR CSM 1.4 (Frölicher et al., 2009), which was forced with the SRES A2 emissions scenario (Nakićenović and Swart, 2000). While the atmospheric $p \mathrm{CO}_{2}$ was taken directly from the NCAR model, the lateral DIC concentrations were determined by combining the present-day DIC field from GLODAP and adding to them the annual increment of DIC from the NCAR CSM 1.4 carbon model simulation. DIC and atmospheric $p \mathrm{CO}_{2}$ at the lateral boundaries were the only forcings that changed over the years, while the atmospheric physical forcings, as well as the lateral boundary conditions of Alk, $T, S$, nutrients and circulation remained unchanged from their seasonal climatologies for the entire simulation from 1995 to 2050. For the preindustrial time-slice simulation, the atmospheric $p \mathrm{CO}_{2}$ was set to a preindustrial value of $280 \mathrm{ppm}$, and the lateral DIC boundary conditions were taken from the preindustrial fields of GLODAP (Key et al., 2004).

In order to analyze the sensitivity of our results toward the chosen SRES emissions scenario, we compared the results of two additional transient simulations that follow both the "high- $\mathrm{CO}_{2}$ " SRES emissions scenario A2 described above, and the "low- $\mathrm{CO}_{2}$ " SRES emissions scenario B1 (Figs. A2 and A3). Due to computational constraints, these two addi-

\footnotetext{
${ }^{2}$ http://www.nodc.noaa.gov/OC5/WOA05/pr_woa05.html
}

tional simulations were conducted with a coarser-resolution setup of $15 \mathrm{~km}$ (Gruber et al., 2012). By 2050, atmospheric $p \mathrm{CO}_{2}$ increased to $492 \mathrm{ppm}$ in the $\mathrm{B} 1$ scenario, compared to $541 \mathrm{ppm}$ in the A2 scenario.

\subsection{Study area}

As our primary interest is the nearshore area, we largely restricted our analyses to the first $50 \mathrm{~km}$ in an east-west direction along the coast (Fig. 1, within light blue line). With regard to depth, we analyzed $\mathrm{pH}$ and $\Omega_{\text {arag }}$ at two distinct depths, i.e., the surface and $100 \mathrm{~m}$, in order to retain the full spatial variability of $\mathrm{pH}$ and $\Omega_{\mathrm{arag}}$, which would have been lost by averaging over the euphotic zone. We also divided the CCS into three subregions defined by Dorman and Winant (1995), based on distinct regional differences in the wind and temperature patterns that potentially affect the dynamics of $\mathrm{pH}$ and $\Omega_{\mathrm{arag}}$. The region north of Cape Mendocino $\left(40.5^{\circ} \mathrm{N}\right)$ is subsequently denoted as the "northern" (blue), the region between Cape Mendocino and Point Conception $\left(34.5^{\circ} \mathrm{N}\right)$ as the "central" (orange) and the region south of Point Conception as the "southern" (red) subregion (Fig. 1).

\subsection{Temporal resolution of model output}

Our analyses of the modeled evolution of $\mathrm{pH}$ and $\Omega_{\text {arag }}$ from 2005 to 2050 are based on monthly averages, with the temporal resolution primarily having been determined by computational and storage constraints. Although such a monthly time averaging reduces the aliasing of unresolved timescales that would result from the analysis of monthly time-slices, it fails to capture the full variability. In order to determine the degree to which the monthly averages represent the full variability, we conducted a spectral analysis of the two-day model output that we had generated for a limited time period only (2006-2010). Such a two-day output captures nearly all of the variability in our model, because in our climatologically forced simulations, all of the simulated high-frequency variability is driven by mesoscale processes with characteristic time scales of between a few days and several weeks.

For the spectral analysis, we calculated the Welch power density spectrum (PDS) of the Fourier transform of the detrended time series data from each grid cell using a Hann window (Glover et al., 2011). The interval for the frequencies $(f)$ captured with monthly output was set to $a=0.2 \mathrm{yr}^{-1}$ and to $b=6 \mathrm{yr}^{-1}$, according to thresholds given by the NyquistShannon sampling theorem. For the frequencies captured with two-day output, the upper boundary was set to $c=$ $90 \mathrm{yr}^{-1}$. We quantified the amount of total variability across all frequencies from $a$ to $c$ and compared it to the amount of variability occurring in the frequencies from $a$ to $b$. We define $M$ as the percentage of the total variability of surface $\mathrm{pH}$ or $\Omega_{\text {arag }}$ that occurs at frequencies less than $b$ as follows:

$M=\frac{\int_{a}^{b} \operatorname{PDS}(f) \mathrm{d} f}{\int_{a}^{c} \operatorname{PDS}(f) \mathrm{d} f} \cdot 100$. 
A plot of $M$ at the surface (Fig. 2a) reveals that in most areas $(98.5 \%)$ along the US West Coast, the majority of variability of surface-modeled $\mathrm{pH}$ and $\Omega_{\mathrm{arag}}$ occurs at frequencies less than $b$ and can be captured by monthly model output. However, as will be discussed in Sect. 4.1, highfrequency variability can lead to very low $\mathrm{pH}$ and $\Omega_{\text {arag }}$ in some nearshore surface areas. These few areas are limited to about $1.5 \%$ of the nearshore $50 \mathrm{~km}$ along the US West Coast. There, less than $50 \%$ of the total variability of surface $\mathrm{pH}$ can be captured with monthly model output (Fig. 2a, blue).

The time series (Fig. 2b) and the PDS of the Fourier transform (Fig. 2c) of two distinct example locations represent these two extreme cases: in location $1\left(43^{\circ} 35^{\prime} \mathrm{N}\right.$, $124^{\circ} 45^{\prime} \mathrm{W}$ ), the monthly averaged sampling frequency captures $89 \%$, whereas in location $2\left(35^{\circ} 29^{\prime} \mathrm{N}, 121^{\circ} 34^{\prime} \mathrm{W}\right)$, only $49 \%$ of the total variability of surface $\mathrm{pH}$ is captured with monthly modeled means. While in location 1 lowfrequency variability dominates (Fig. 2c, upper panel), highfrequency variability prevails in location 2 (Fig. 2c, lower panel).

At $100-\mathrm{m}$ depth, the majority of variability of modeled $\Omega_{\text {arag }}$ occurs at frequencies less than $b$ (Fig. 3a). Thus the low-frequency variability of $\Omega_{\mathrm{arag}}$ is the most dominant mode along the entire US West Coast (Fig. 3c) and can be very well captured by the monthly averages.

To account for areas where the model variability of $\mathrm{pH}$ and $\Omega_{\text {arag }}$ are not fully captured with monthly average output, we introduce a correction factor $\left(\operatorname{var}_{\mathrm{cf}}\right)$ :

$\operatorname{var}_{\mathrm{cf}}=\sqrt{\frac{\sigma_{\text {two-day }}^{2}}{\sigma_{\text {month }}^{2}},}$

where $\sigma_{\text {two-day }}^{2}$ is the temporal variance of the two-day output of model year 2010 and $\sigma_{\text {month }}^{2}$ is the temporal variance of the monthly averaged, two-day output data of the same year. The correction factor $\operatorname{var}_{\mathrm{cf}}$ varies between 1.2 in the northern and southern CCS and 1.4 in the central CCS and is used to correct the variability envelopes in Sect. 4.4.

Additional high-frequency variability, such as due to synoptic wind-driven upwelling events, for example, cannot be captured with either model output type due to our choice of monthly climatological wind forcing (see Sects. 3 and 5 for further discussion).

\section{Model evaluation}

The model's performance for simulating observed sea surface $T$, surface chlorophyll and the mixed layer depth was already evaluated in Lachkar and Gruber (2011) and Gruber et al. (2006, 2011). The model simulates the observed annual and seasonal patterns of surface temperature well with correlations of $\rho=0.98$ and $\rho=0.95$, respectively. It also captures successfully the offshore extent of the cold upwelling region. The modeled annual mean mixed- layer depth has a correlation of 0.70 with observational data, but has a substantially higher standard deviation relative to the observations. The annual mean pattern of chlorophyll $a$ compares well with the SeaWiFS data set $(\rho=0.80)$, but the model underestimates chlorophyll $a$ in the nearshore $100 \mathrm{~km}$ and has a poorer representation of its seasonal cycle $(\rho=0.46)$. The current paper will supplement these earlier evaluations by comparing the model to in situ data with an emphasis on vertical and cross-shore variability of the key carbonate chemistry properties in the upper ocean (also see Gruber et al., 2012).

First, we evaluate the modeled spatial variability of $\mathrm{pH}$, $\Omega_{\text {arag }}$, DIC, Alk, $T$ and $S$ by comparing it to data from the North American Carbon Program (NACP) West Coast Cruise (Feely et al., 2008) (Fig. 1, yellow dots, lines 4-11). The observational data were sampled between May and June 2007. For the comparison, we averaged model output of May and June from 2006 through 2010 and linearly interpolated it to a vertical grid with $1 \mathrm{~m}$ resolution. The model data were averaged over this 5-year period in order to remove any modelbased interannual variability that could bias the results of the model evaluation.

A visual comparison of the modeled versus observed vertical distributions of the studied variables, along a representative transect line (off Pt. St. George, California, Fig. 1, yellow arrow), indicates that the offshore pattern between 0 and $100 \mathrm{~m}$ is captured well (Fig. 4). However, the model underestimates the magnitude of the vertical difference of DIC $(\sim 20 \mu \mathrm{mol} \mathrm{kg}-1)$ in waters deeper than $\sim 125 \mathrm{~m}$. In the nearshore region between 0 and $250 \mathrm{~m}$ depth, the model underestimates Alk by $10-35 \mu \mathrm{mol} \mathrm{kg}-1$ and especially DIC by $40-150 \mu \mathrm{mol} \mathrm{kg}^{-1}$. The larger bias (b) in DIC is the primary cause of the overestimation of the simulated $\mathrm{pH}$ $\left(b_{\mathrm{pH}} \sim 0.2\right)$ and $\Omega_{\mathrm{arag}}\left(b_{\Omega_{\mathrm{arag}}} \sim 0.5\right)$, since their sensitivities toward changes in Alk and DIC are similar. As a result, our modeled aragonite saturation horizon is typically $60 \mathrm{~m}$ deeper than the observed one, and up to $150 \mathrm{~m}$ deeper during the strongest upwelling events. There is no obvious difference in model performance between subregions, i.e., $\mathrm{pH}$ and $\Omega_{\text {arag }}$ are modeled equally well for all three subregions, with a Pearson correlation coefficient of about $\rho_{\mathrm{pH}}=0.89$ 0.90 between observed and modeled $\mathrm{pH}$ and $\rho_{\Omega_{\mathrm{arag}}}=0.88$ 0.90 for $\Omega_{\text {arag }}$ (Fig. 5). The normalized standard deviations, correlation coefficients and biases between all observed and modeled properties can be found in Table A2.

The nearshore positive bias of $\mathrm{pH}$ and $\Omega_{\text {arag }}$ may be partially a result of transect line 5 having been sampled during strong upwelling conditions (Feely et al., 2008). Our model does not simulate such events since it is only forced with a monthly climatology of wind, but not with specific weather patterns and variability. The absence of such an intense upwelling event can be observed in all simulated variables shown in Fig. 4. The observed, strong outcrop nearshore indicates a vigorous upwelling, which is considerably underestimated by our model. This caveat was described by 
(a)

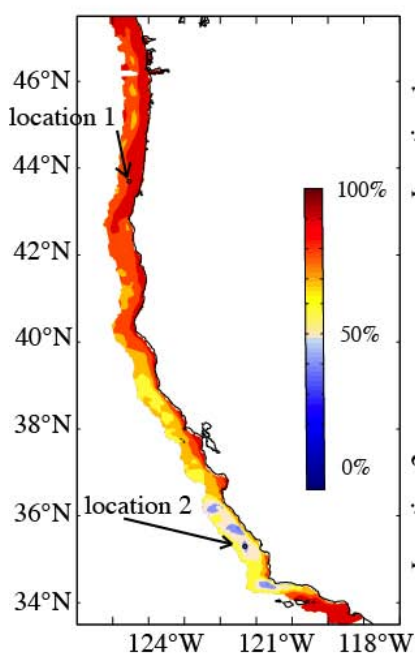

(b)
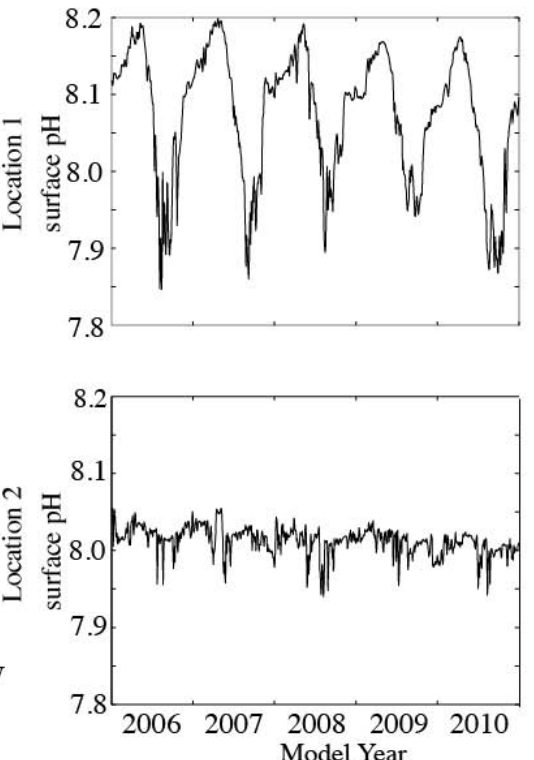

(c)
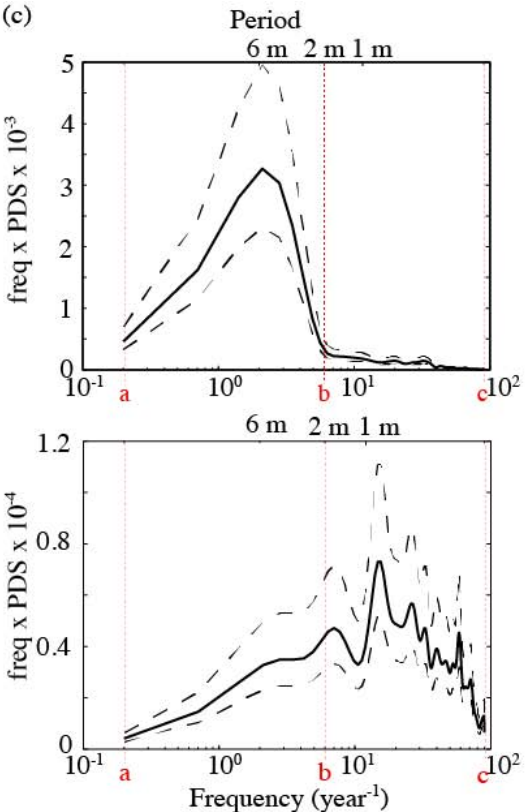

Fig. 2. Analysis of variability of surface $\mathrm{pH}$. (a) indicates the percentage of the total variability of surface $\mathrm{pH}$ that occurs at frequencies less than $b=6 \mathrm{yr}^{-1}$. The arrows point out the locations of the two example sites described in panels (b) and (c). (b) Time series of surface $\mathrm{pH}$ over $5 \mathrm{yr}$ for two distinct example locations and (c) a variance-conserving plot of the frequency $\times$ power density spectrum (PDS) vs. the frequency of the Fourier transformed time series. The black solid line represents the PDS and the black dashed lines envelope the $\pm 95 \%$ confidence interval. The red dashed lines show the boundaries $a, b$ and $c$ of the integrals applied in Eq. (1).

(a)

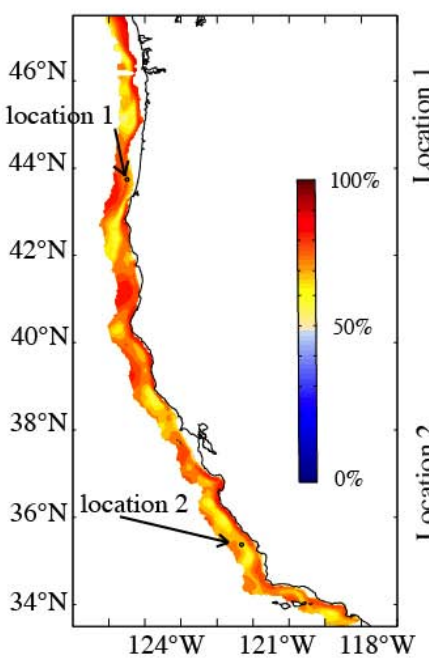

(b)
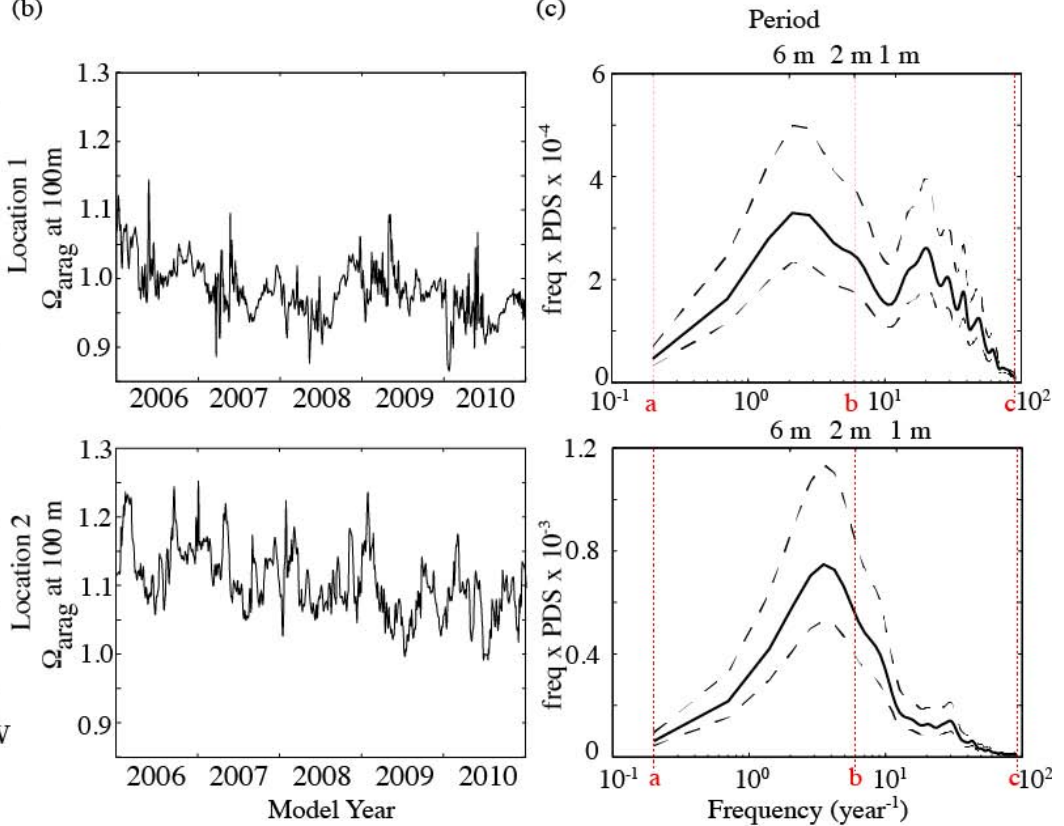

Fig. 3. Analysis of variability of $\Omega_{\text {arag }}$ at $100 \mathrm{~m}$. (a) indicates the percentage of the total variability of $\Omega_{\text {arag }}$ at $100 \mathrm{~m}$ that occurs at frequencies less than $b=6 \mathrm{yr}^{-1}$. The arrows point out the locations of the two example sites described in panels (b) and (c). (b) Time series of $\Omega_{\mathrm{arag}}$ at $100 \mathrm{~m}$ over $5 \mathrm{yr}$ for two distinct example locations and (c) a variance-conserving plot of the frequency $\times$ power density spectrum (PDS) vs. the frequency of the Fourier transformed time series. The black solid line represents the PDS and the black dashed lines envelope the $\pm 95 \%$ confidence interval. The red dashed lines show the boundaries $a, b$ and $c$ of the integrals applied in Eq. (1). 


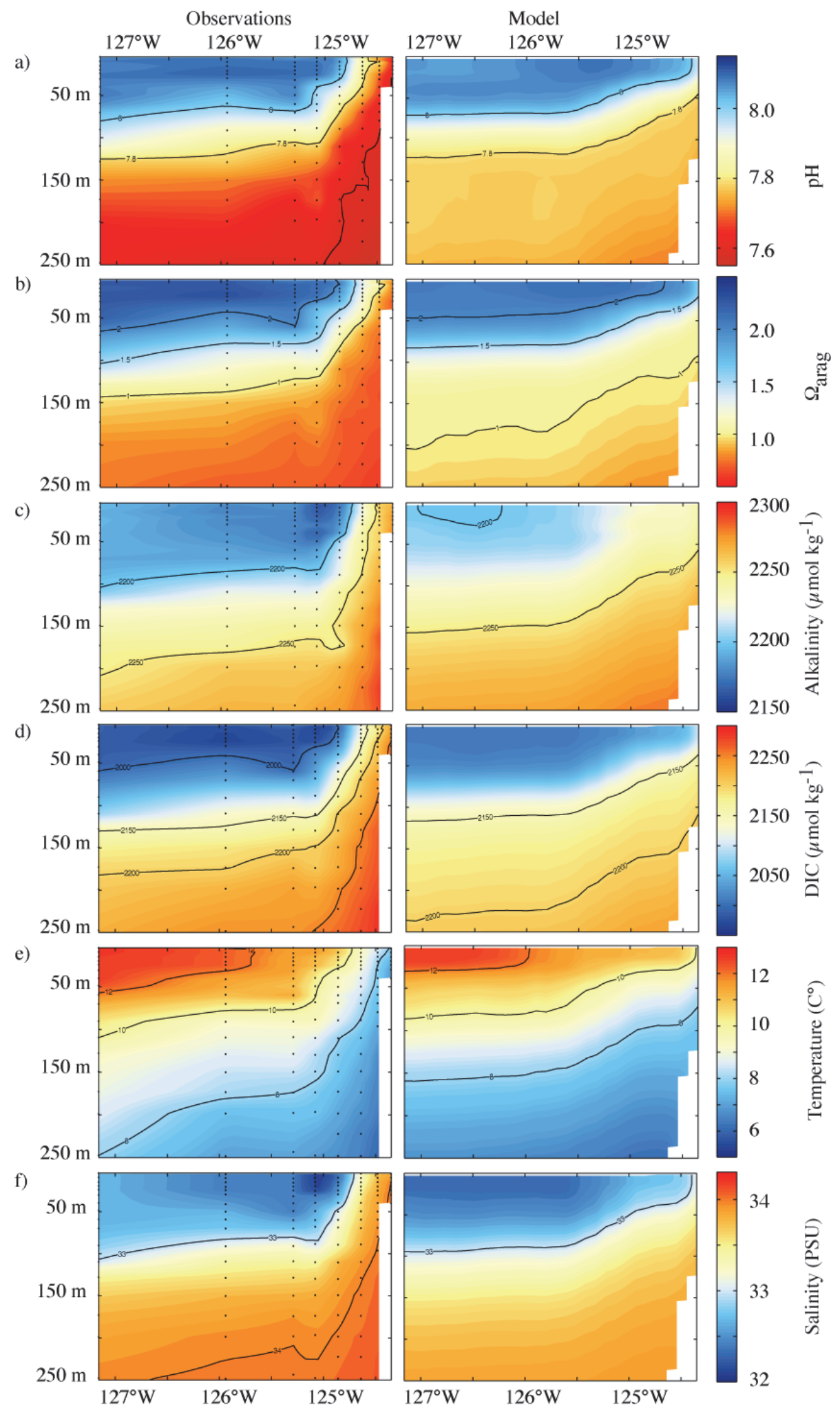

Fig. 4. Vertical sections of (a) $\mathrm{pH}$, (b) $\Omega_{\text {arag }}$, (c) alkalinity, (d) DIC, (e) temperature and (f) salinity of observations (left, Feely et al., 2008) and the corresponding model output (right), off Pt. St. George, California. A five-year average of model parameters over May and June (2006-2010) is compared to observations sampled between May and June 2007. The black dots represent sample locations. 

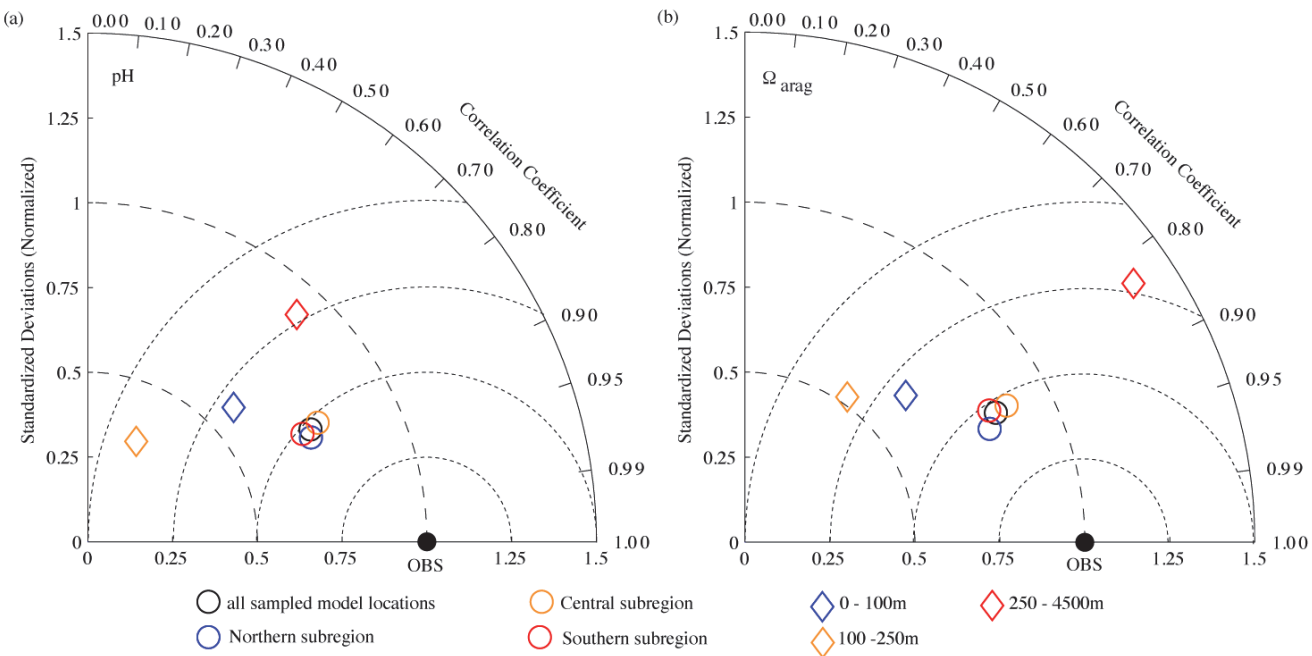

Fig. 5. Taylor diagram (Taylor, 2001) of model simulated (a) $\mathrm{pH}$ and (b) $\Omega_{\text {arag }}$ compared to observations (Feely et al., 2008). A fiveyear average of parameters over May and June (2006-2010) are compared to observations sampled between May and June 2007, for all sampled locations (black), the northern (blue circle), central (orange circle), and southern subregions (red circle), and for 0-100 $\mathrm{m}$ (blue diamond), 100-250 $\mathrm{m}$ (orange diamond) and 500-5000 $\mathrm{m}$ (red diamond). The distance from the origin is the normalized standard deviation of the modeled parameters. The azimuth angle represents the correlation between the observations and the modeled parameters The distance between the model point and the observation point (filled ellipse on the abscissa) indicates the normalized root mean square (RMS) misfit between model and observational estimates.

Gruber et al. (2006, 2012); Lachkar and Gruber (2011) and we focus on the implications of this discrepancy in the Discussion.

We evaluate the temporal variability of $\mathrm{pH}, \Omega_{\mathrm{arag}}$, Alk, DIC, $T$ and $S$ by comparing our model results to a seasonal climatology from the Southern California Bight, generated from roughly bi-weekly samples obtained from the Santa Monica Bay Observatory Mooring at $33^{\circ} 55.9^{\prime} \mathrm{N}$ and $118^{\circ} 42.9^{\prime} \mathrm{W}$ from 2003 to 2008 (Leinweber and Gruber, 2013). The model-based climatology for the same site and time-period underestimates $\mathrm{pH}$ and $\Omega_{\text {arag }}$ at depth (Fig. 6) as evidenced already in the comparisons with the NACP West Coast Cruises. In addition, the observations show high temporal variability at the surface $\left(\sigma_{\mathrm{pH}}=0.08,1 \mathrm{STD}\right.$ for the full observational record and $\sigma_{\Omega_{\text {arag }}}=0.40$ ) and at depth $\left(\sigma_{\mathrm{pH}}=0.07\right.$ and $\left.\sigma_{\Omega_{\mathrm{arag}}}=0.20\right)$, which is underestimated by the model by a factor of about 7 for surface $\Omega_{\text {arag }}$ and by a factor of about 3.5 for surface $\mathrm{pH}$ and both variables at $100 \mathrm{~m}$. The observed high spatial and temporal variability of $\mathrm{pH}$ and $\Omega_{\text {arag }}$ of the southern CCS is dominated by highfrequency winds (Capet et al., 2004) that are not resolved in our current forcing files. Moreover, in the model, the bottom topography is smoothed over the continental shelf to prevent numerical instabilities associated with complex bathymetry. Therefore, the variability resulting from the interaction of the flow field with the observed bathymetry, particularly in the southern CCS, is not fully represented.

Better agreements with the observed temporal variability is achieved by the model for most other regions for which data are available. A comparison with new $\mathrm{pH}$ and $\Omega_{\text {arag }}$ data derived from a surface mooring off Newport, OR $\left(44^{\circ} 38^{\prime} 0^{\prime \prime} \mathrm{N} 124^{\circ} 18^{\prime} 13^{\prime \prime} \mathrm{W}\right.$, Harris et al., 2013) from 2009 to 2011 demonstrates that the modeled temporal variability $\left(\sigma_{\mathrm{pH}}=0.10\right.$ and $\left.\sigma_{\Omega_{\mathrm{arag}}}=0.32,1 \mathrm{STD}\right)$ agrees well with the observed temporal surface variability $\left(\sigma_{\mathrm{pH}}=0.11\right.$ and $\sigma_{\Omega_{\text {arag }}}=0.37,1 \mathrm{STD}$ ). Also, the model is in better agreement with the temporal variability of $\mathrm{pH}$ and $\Omega_{\mathrm{arag}}$ in nearshore subsurface regions just north of Point Conception (Alin et al., 2012) than in the southern CCS. Alin et al. (2012) estimated $\mathrm{pH}$ and $\Omega_{\text {arag }}$ based on seasonal hydrographic data from CalCOFI line 76.7 from 2005 to 2010. Their estimated temporal variability of $\sigma_{\mathrm{pH}}=0.09$ and $\sigma_{\Omega_{\text {arag }}}=0.32$ at $30 \mathrm{~m}$ depth are by a factor of 1.2 and 1.5 , respectively, greater than the modeled temporal variability $\left(\sigma_{\mathrm{pH}}=0.07\right.$ and $\left.\sigma_{\Omega_{\mathrm{arag}}}=0.21\right)$. The model-data misfit increases with depth. At $100 \mathrm{~m}$ depth, the model underestimates the temporal variability of $\Omega_{\text {arag }}$ by a factor of 2 and by a factor of 5.5 for $\mathrm{pH}$.

In summary, there are two main model shortcomings that influence the results presented here (also see Discussion). $\mathrm{pH}$ and $\Omega_{\text {arag }}$ are overestimated at depth and in nearshore surface areas, resulting in a deeper aragonite saturation horizon than observed. Secondly, the modeled temporal variability of $\mathrm{pH}$ and $\Omega_{\text {arag }}$ is underestimated. According to available observations, this bias is largest in the southern CCS and at depth and decreases toward the north. Due to the limited spatial and temporal coverage of observational data in the CCS, this model-data comparison serves as preliminary 


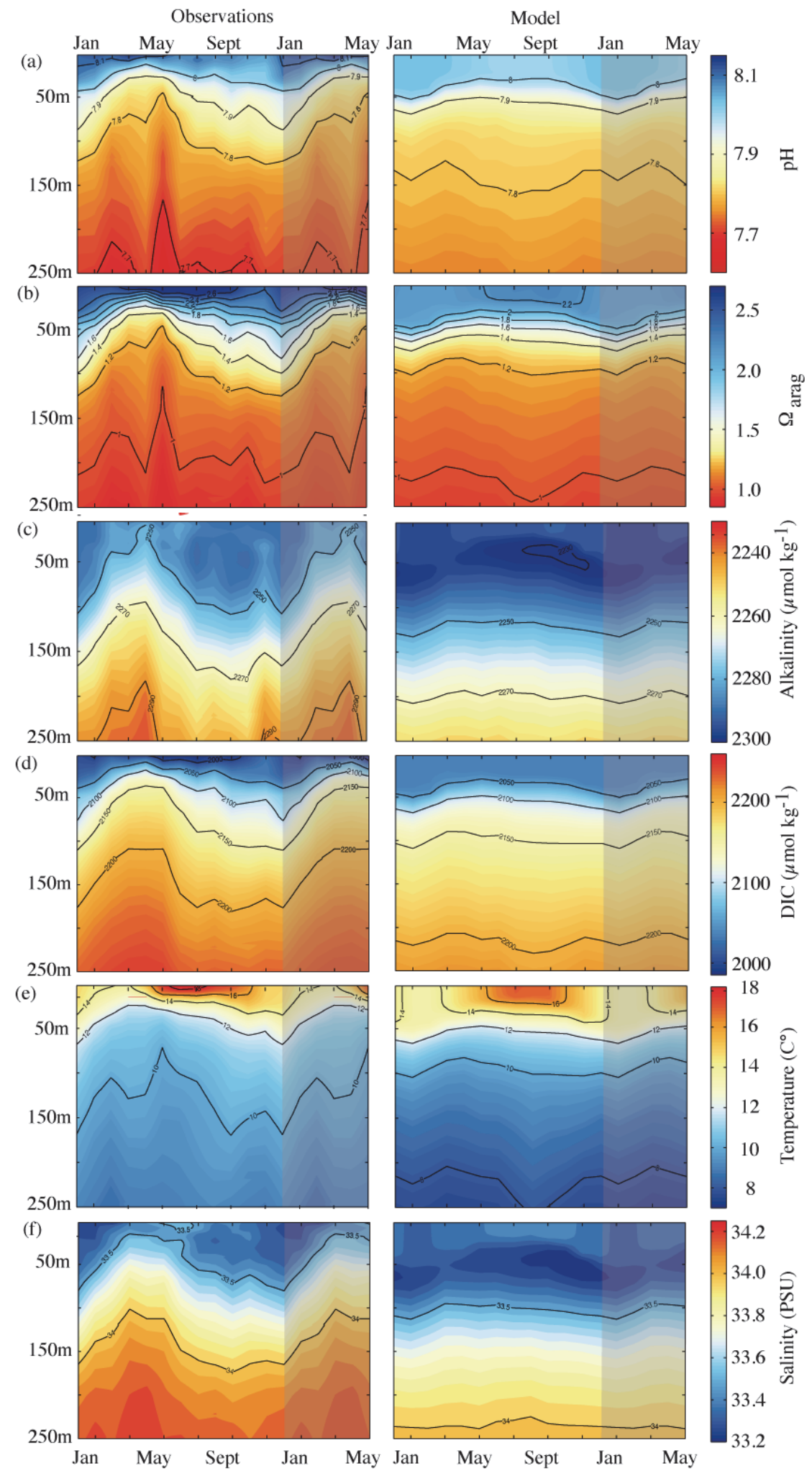

Fig. 6. Comparison of bi-weekly observed (2003-2008; Santa Monica Bay Observatory Mooring) and model simulated climatologies of (a) $\Omega_{\text {arag }},(\mathbf{b}) \mathrm{pH}$, (c) alkalinity, (d) DIC, (e) temperature and (f) salinity at 0-250 m between 2005 and 2010. The shaded area depicts the first six months of the following annual cycle. 
model evaluation and should be revised once additional observational data are available.

\section{Results}

Here, we discuss the range and magnitude of changes in $\mathrm{pH}$ and $\Omega_{\text {arag }}$ and explore the drivers and mechanisms of the temporal and spatial variability in the nearshore environment of the CCS. We then present projections of the evolution of $\mathrm{pH}$ and $\Omega_{\text {arag }}$ until 2050 and determine the timing of when the chemical characteristics within the different subregions move outside of their modeled preindustrial and present-day variability envelopes (relative threshold). Finally, we project when the absolute threshold of aragonite undersaturation is reached.

\subsection{Spatial and temporal patterns of modeled $\mathrm{pH}$ and $\Omega_{\text {arag }}$}

Examples of the modeled monthly averages for surface $\mathrm{pH}$ of model year 2011 ( $p \mathrm{CO}_{2} \sim 395 \mathrm{ppm}$ ) show that the waters within the first $50 \mathrm{~km}$ of the CCS experience a wide range of surface $\mathrm{pH}$ from 7.85 to 8.15 (Fig. 7a). Spatial variability of surface $\mathrm{pH}$ is highest in the central subregion $\left(\sigma_{\mathrm{pH}}=0.10\right.$, $1 \mathrm{STD}$ ) around July, while it is small and constant in the southern subregion (Fig. 8a and b). In the central nearshore $\mathrm{CCS}$, the lowest surface $\mathrm{pH}\left(\mathrm{pH}_{\min }=7.85\right)$ is simulated between June and September. The highest nearshore surface $\mathrm{pH}$ $\left(\mathrm{pH}_{\max }=8.15\right)$ is reached between November and March in the northern subregion, while the central CCS only experiences high surface $\mathrm{pH}\left(\mathrm{pH}_{\max }=8.05\right)$ during three months (January-March). In the central CCS, surface $\mathrm{pH}$ decreases to 7.95 around June and increases to around 8.05 in January. Farther off the coast, surface $\mathrm{pH}$ of the northern subregion remains at around 8.10 , while in the central and southern CCS it drops from 8.15 to 8.00 . At $100 \mathrm{~m}$ depth, low $\mathrm{pH}$ of about 7.75 extends to about $300 \mathrm{~km}$ offshore all year round and in the entire CCS, except along the Washington coast, where $\mathrm{pH}$ remains close to about 8.10 between April and July, and drops to about 7.65 between August and October (not shown).

The seasonal evolution of surface $\Omega_{\text {arag }}$ (not shown) behaves similarly to surface $\mathrm{pH}$. The modeled monthly means do not show undersaturation at the surface. However, model results from averaged two-day model output reveal that north of Cape Mendocino, surface pH can drop down to 7.72 (Fig. 7c) and surface $\Omega_{\text {arag }}$ to 0.93 , below the values captured by the monthly mean outputs. In nearshore areas at $100 \mathrm{~m}$ depth, aragonite undersaturation is also simulated in late fall, most likely due to the remineralization of the sinking organic matter that was produced during the summer phytoplankton blooms (Fig. 7b). Spatial variability of both parameters and along the entire US West Coast is constant and small (Fig. 8a and b).
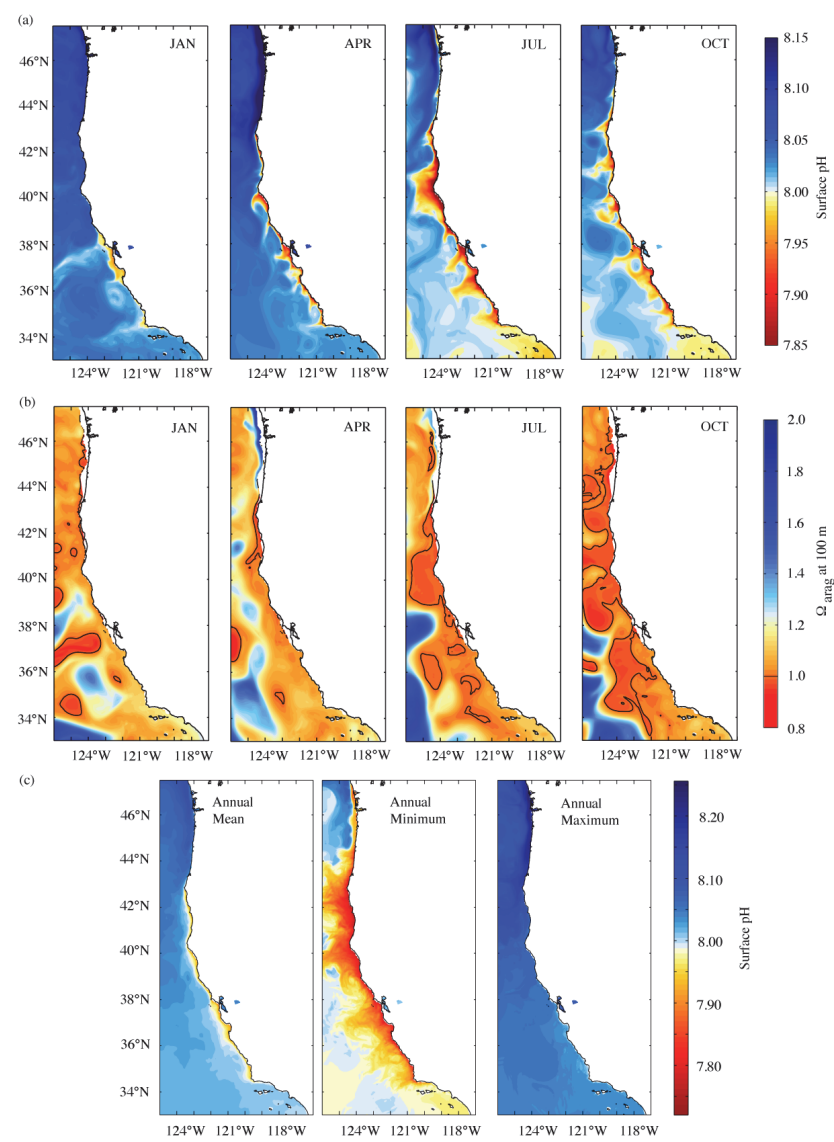

Fig. 7. Simulated monthly averages of (a) surface $\mathrm{pH}$ and (b) $\Omega_{\text {arag }}$ at $100 \mathrm{~m}$. Shown are January, April, July and October of model year 2011 ( $2395 \mathrm{ppm}$ atmospheric $\left.p \mathrm{CO}_{2}\right)$. (c) Mean, minimum and maximum values of surface $\mathrm{pH}$ from two-day model output.

\subsection{Spatially averaged seasonal cycle of $\mathrm{pH}$ and $\Omega_{\text {arag }}$ for each subregion}

The range of the mean seasonal cycle of $\mathrm{pH}$ and $\Omega_{\text {arag }}$ varies from region to region in the CCS (Fig. 8a and b) and is more pronounced at the surface than at $100 \mathrm{~m}$. The northern subregion has the highest annual mean surface $\mathrm{pH}(\overline{\mathrm{pH}}=8.07)$ and the most distinct seasonal cycle (Fig. 8a), with a range of about $0.14 \mathrm{pH}$ units. In the central and southern CCS, the average surface $\mathrm{pH}$ is $\overline{\mathrm{pH}}=8.00$ with a range of 0.09 and 0.04 , respectively. While surface $\mathrm{pH}$ is lowest in August and September in the northern subregion, the central subregion shows the lowest surface $\mathrm{pH}\left(\mathrm{pH}_{\min }=7.95\right)$ in June.

The annual mean surface $\Omega_{\mathrm{arag}}$ is 2.02 in the northern and 1.88 in central CCS and is highest $\left(\Omega_{\text {arag }}^{\max }=2.14\right)$ in the southern subregion (Fig. 8b). Surface $\Omega_{\text {arag }}$ decreases to 1.85 in August and September in the northern subregion. The central subregion shows the lowest surface $\Omega_{\text {arag }}\left(\Omega_{\text {arag }}^{\min }=1.73\right)$ in June. In the southern CCS, surface $\Omega_{\text {arag }}$ increases slightly during the summer months. 


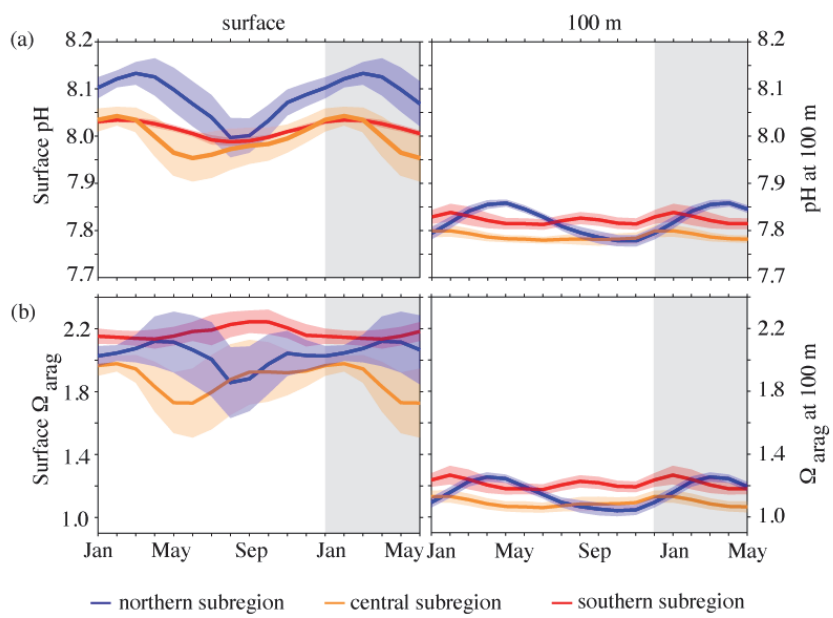

Fig. 8. Seasonal cycle of (a) $\mathrm{pH}$ and (b) $\Omega_{\text {arag }}$ in the nearshore $50 \mathrm{~km}$. The lines represent the mean and the shaded area the spatial variability ( \pm 1 STD) for each month, for the northern (blue), central (orange) and southern (red) subregions, at the surface (left) and at $100 \mathrm{~m}$ (right). The shaded area depicts the first six months of the following annual cycle.

At $100 \mathrm{~m}$ depth, average $\mathrm{pH}$ remains around 7.8 and average $\Omega_{\text {arag }}$ around 1.1 in all three subregions.

\subsection{Mechanisms influencing the seasonal cycle in $\mathrm{pH}$ and $\Omega_{\text {arag }}$}

To understand the mechanisms causing the seasonal changes in $\mathrm{pH}$ and $\Omega_{\text {arag }}$ across the three subregions, we investigate their sensitivity to the seasonal variations in Alk, DIC, $T$ and $S$. To do so, we estimate the contribution of changes in each property to the total change of $\mathrm{pH}$ and $\Omega_{\text {arag. The change in }}$ $\mathrm{pH}$ and $\Omega_{\mathrm{arag}}$ can be "separated" using a Taylor expansion in first order of all considered variables:

$$
\begin{aligned}
\Delta \mathrm{pH} & =\frac{\partial \mathrm{pH}}{\partial \mathrm{DIC}} \Delta_{\mathrm{s}} \mathrm{DIC}+\frac{\partial \mathrm{pH}}{\partial \mathrm{Alk}} \Delta_{\mathrm{S}} \mathrm{Alk}+\frac{\partial \mathrm{pH}}{\partial T} \Delta T \\
& +\Delta \mathrm{FS}_{\mathrm{pH}}+\text { Res },
\end{aligned}
$$

where

$$
\Delta \mathrm{FS}_{\mathrm{pH}}=\frac{\partial \mathrm{pH}}{\partial S} \Delta S+\frac{\partial \mathrm{pH}}{\partial \mathrm{DIC}} \Delta \mathrm{DIC}^{\mathrm{s}}+\frac{\partial \mathrm{pH}}{\partial \mathrm{Alk}} \Delta \mathrm{Alk}^{\mathrm{s}}
$$

and

$$
\begin{aligned}
\Delta \Omega & =\frac{\partial \Omega}{\partial \mathrm{DIC}} \Delta_{\mathrm{s}} \mathrm{DIC}+\frac{\partial \Omega}{\partial \mathrm{Alk}} \Delta_{\mathrm{s}} \mathrm{Alk}+\frac{\partial \Omega}{\partial T} \Delta T \\
& +\Delta \mathrm{FS}_{\Omega}+\text { Res },
\end{aligned}
$$

where

$$
\Delta \mathrm{FS}_{\Omega}=\frac{\partial \Omega}{\partial S} \Delta S+\frac{\partial \Omega}{\partial \mathrm{DIC}} \Delta \mathrm{DIC}^{\mathrm{s}}+\frac{\partial \Omega}{\partial \mathrm{Alk}} \Delta \mathrm{Alk}^{\mathrm{s}} .
$$

The partial derivatives quantify the differential changes in carbon chemistry due to small changes in DIC, Alk, $T$ and $S$ and are derived from model equations and annual means of a modeled climatology (2006-2010). $\Delta_{\mathrm{S}}$ DIC and $\Delta_{\mathrm{S}}$ Alk are the salinity normalized deviations from the annual means of DIC and Alk; $\triangle \mathrm{DIC}^{\mathrm{S}}$ and $\Delta \mathrm{Alk}^{\mathrm{s}}$ are deviations from the annual means due to freshwater input, and $\Delta \mathrm{FS}_{\mathrm{pH}}$ and $\Delta \mathrm{FS}_{\Omega}$ are the total contributions of freshwater input to the change in $\mathrm{pH}$ and $\Omega_{\text {arag }}$, respectively. Residuals (= Res.) capture the error when the left- and right-hand side of the equation are not equal.

The seasonal variations in $\mathrm{pH}$ and $\Omega_{\mathrm{arag}}$ are driven by a combination of seasonal changes in DIC, Alk and $T$. These parameters are altered by upwelling and eddies, which differ in magnitude and timing from region to region (Figs. 9 and 10). In addition, Alk changes due to the precipitation or dissolution of $\mathrm{CaCO}_{3}$, and due to nitrification and nitrate assimilation during new production (see Sect. 2.1, Appendix A). DIC changes due to $\mathrm{CaCO}_{3}$ calcification and dissolution, net primary production and heterotrophic respiration. Surface temperature reflects changes in the incoming solar radiation and heat exchange with the atmosphere. Figures 9 and 10 show the contributions of changes in DIC, Alk, $S$ and $T$ to changes (relative to the annual mean) in $\mathrm{pH}$ and $\Omega_{\text {arag }}$, respectively. Each colored component represents the corresponding term in Eqs. (4) and (6). Components that plot in a positive direction have a positive effect on $\mathrm{pH}$ or $\Omega_{\text {arag }}$. Therefore, the sum of all components lead to the total effect of $\mathrm{pH}$ and $\Omega_{\mathrm{arag}}$, resulting in either an addition or cancellation of the effect on $\mathrm{pH}$ or $\Omega_{\mathrm{arag}}$. $\mathrm{pH}$ is negatively correlated to changes in DIC, $T$ and $S$, but has a positive correlation with changes in Alk. While the correlations for $\Omega_{\text {arag }}$ with Alk, DIC and $S$ are the same as for $\mathrm{pH}$, changes in $\Omega_{\text {arag }}$ are positively correlated to changes of $T$.

In the northern CCS, the effects of the changes in DIC and $T$ on surface $\mathrm{pH}$ are counteracted by changes in Alk at the beginning of the upwelling season in spring and amplified in late summer and early fall (Fig. 9a). With a small delay, $T$ amplifies the effect of changes in DIC on surface $\mathrm{pH}$ throughout the year. The upwelling of DIC-rich water decreases surface $\mathrm{pH}$ beginning in April. Upwelled subsurface waters increase Alk at the surface during upwelling. The increase in Alk compensates for the upwelled DIC-rich water and warming of the surface waters until Alk reaches its peak in June. By August, Alk has declined to a minimum, which then amplifies the effects of DIC and $T$ to create the $\mathrm{pH}$ minimum.

In the central CCS, upwelling starts in March, one month earlier than in the northern subregion (Fig. 9). The upwelled, DIC-enriched subsurface waters decrease surface $\mathrm{pH}$ to its minimum in June. In spring, DIC is the main driver of seasonal changes of $\mathrm{pH}$. Increased primary production (Fig. A1a) decreases DIC as from June. Warming of surface waters in late summer delays the effect of declining DIC on $\mathrm{pH}$. In winter, $T$ and Alk both amplify the effect of DIC, leading to a pH maximum in February.

In the southern CCS, changes in $\mathrm{pH}$ in the model are mainly driven by the incoming solar radiation and heat 


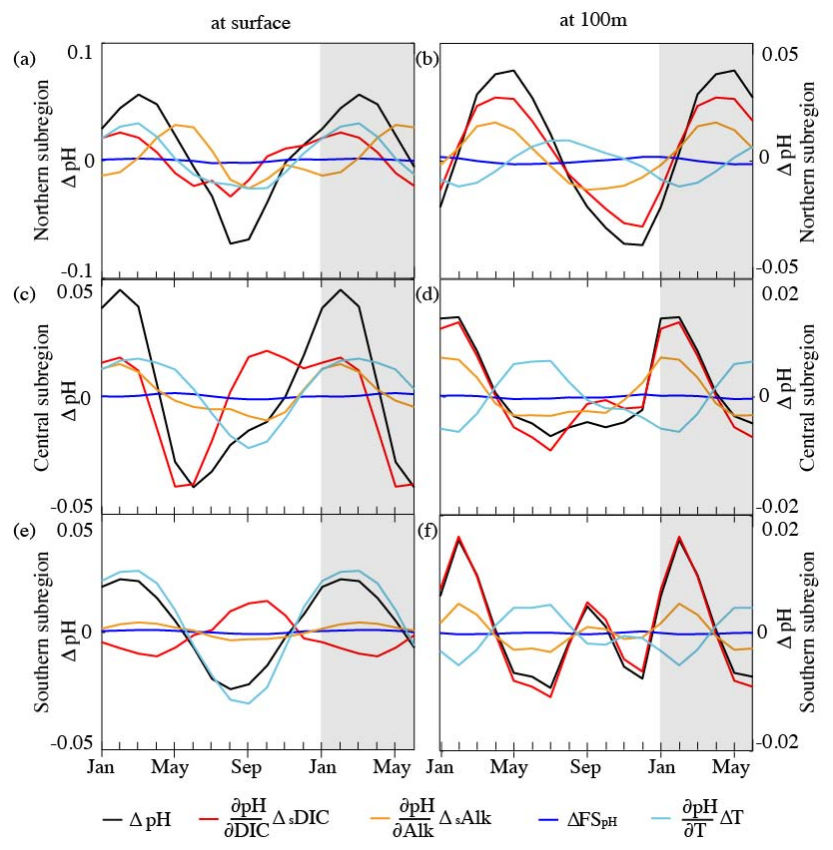

Fig. 9. Contributions of changes in DIC (red), alkalinity (orange), salinity (blue, freshwater flux, FS) and temperature (light blue) to changes (relative to the annual mean) in $\mathrm{pH}$ (black) at the surface and at $100 \mathrm{~m}$ depth for the northern (top panels, $\mathbf{a}$ and $\mathbf{b}$ ), central (center panels, $\mathbf{c}$ and $\mathbf{d}$ ) and southern (bottom panels, e and f) subregions. Note different y-axis scales. The shaded area depicts the first six months of the following annual cycle.

exchange with the atmosphere (Fig. 9e), which decreases $\mathrm{pH}$ in summer, when sea surface temperature increases. The seasonal cycle of DIC is out of phase with the seasonal cycle of surface $T$ and slightly counteracts the effect of $T$ on $\mathrm{pH}$. The warming of the surface waters lead to a late summer $\mathrm{pH}$ minimum.

At $100 \mathrm{~m}$ depth, the effects of Alk in the northern CCS (Fig. 9b) are in concert with the seasonal effects of DIC. Changes in temperature play a minor role. The absence of upwelling in the winter months leads to high $\mathrm{pH}$ levels in all subregions. Upwelling starts earlier in the southern (Fig. 9f) than northern CCS, shown by the earlier increase of DIC (decrease of $\mathrm{pH}$ ) in the southern than in the northern subregion. In the central (Fig. 9d) and southern subregions, DIC is the main driver of $\mathrm{pH}$, except during the upwelling season, when cold, upwelled waters counteract the effect of DIC on $\mathrm{pH}$. The cold temperature of the upwelled waters dampen the early summer $\mathrm{pH}$ decrease in the central and southern CCS. Nitrification (Fig. A1b) sets in in March (southern CCS), in April (central CCS) or in June (northern CCS), decreases Alk, amplifies the decreasing effect of DIC on $\mathrm{pH}$ and counteracts the cold temperature effect.

The analysis of the contributions to the seasonal changes in $\Omega_{\text {arag }}$ reveal that Alk has a much higher influence on $\Omega_{\text {arag }}$ in the northern subregion than it does in the central or

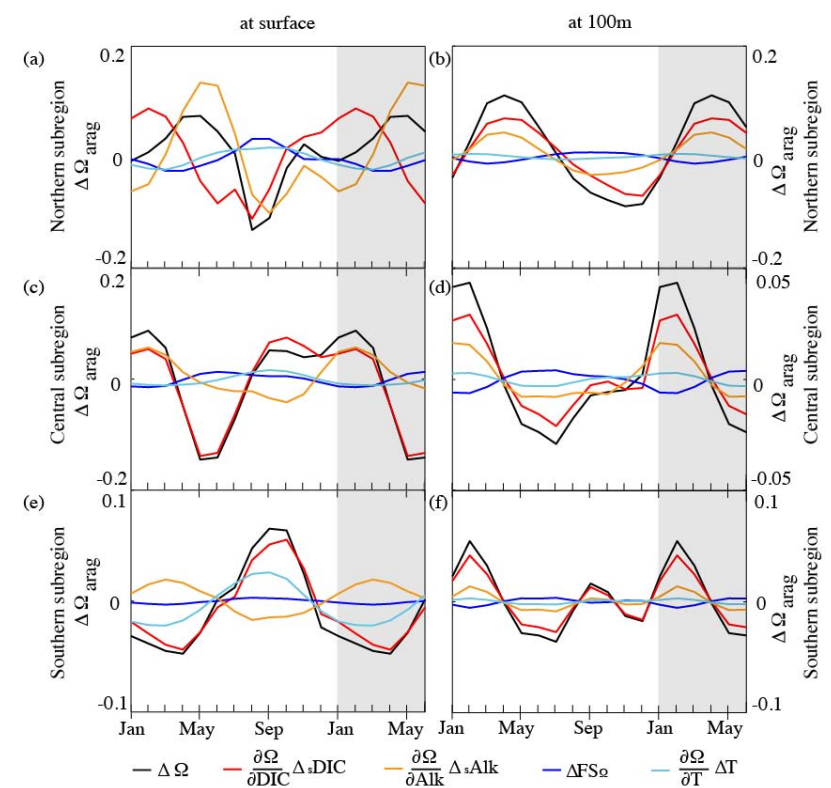

Fig. 10. Contributions of changes in DIC (red), alkalinity (orange), salinity (blue, freshwater flux, FS) and temperature (light blue) to changes (relative to the annual mean) in $\Omega_{\text {arag (black) at the surface }}$ and at $100 \mathrm{~m}$ depth for the northern (top panels, $\mathbf{a}$ and $\mathbf{b}$ ), central (center panels, $\mathbf{c}$ and $\mathbf{d}$ ) and southern (bottom panels, $\mathbf{e}$ and $\mathbf{f}$ ) subregions. Note different y-axis scales. The shaded area depicts the first six months of the following annual cycle.

southern CCS (Fig. 10). Upwelling brings waters enriched in DIC and Alk to the surface. In the northern CCS, the resulting increase in surface DIC is substantially mitigated by the strong positive net community production that removes most of the "new" DIC provided by upwelling. In contrast, the upwelling-induced increase in Alk is barely mitigated, as the relatively small reduction in Alk caused by the net formation of $\mathrm{CaCO}_{3}$ is in part offset by the increase in $\mathrm{Alk}$ caused by the positive net community production. Taken together, during spring the changes in $\Omega_{\mathrm{arag}}$ are driven primarily by the upwelling of Alk (Fig. 10a). The decrease of surface $\Omega_{\text {arag }}$ is thus delayed and changes in $\Omega_{\text {arag }}$ are suppressed. In July, Alk decreases rapidly, which amplifies the effect of rising DIC concentrations on $\Omega_{\text {arag }}$, thereby causing its minimum. In the central and southern CCS, surface $\Omega_{\text {arag }}$ is mainly driven by the changes of DIC (Fig. 10c and e). Upwelling in the central subregion starts in March and increases surface DIC and thus decreases $\Omega_{\mathrm{arag}}$. From June to August, primary production causes a decrease in DIC, and an increase in $\Omega_{\text {arag. }}$. Unlike for $\mathrm{pH}$, surface water warming has a positive effect on $\Omega_{\text {arag }}$ in the southern CCS and amplifies the effects of the seasonal cycle of DIC.

At 100-m depth, Alk amplifies the effects of DIC on $\Omega_{\text {arag }}$ in all subregions (Fig. 10b, d, f). Respiration of sinking particles from the surface, coupled with high levels of nitrification, cause a decrease in Alk which amplifies the effects of 
the upwelled DIC-rich water on $\Omega_{\text {arag }}$, which leads to a minimum of $\Omega_{\text {arag }}$ at the end of the season (Fig. A1b).

\subsection{Temporal and spatial variability vs. future trends}

In this section, we determine the timing of when the trajectories of $\mathrm{pH}$ and $\Omega_{\mathrm{arag}}$ diverge from the ranges of variability that occurred during the preindustrial and the present-day time periods. To accomplish this, we defined preindustrial (1750), present-day (2011), and future variability envelopes. These variability envelopes were calculated by first computing the moving average (over a 10-yr window) of the regionally averaged monthly time series from the model. Secondly, we added and subtracted the ten-year moving standard deviation of the detrended regionally averaged monthly time series. As noted in Sect. 2, we corrected the magnitude of these modeled variability envelopes by a factor var $_{\mathrm{cf}}$ that accounts for the underestimation of variability due to the usage of monthly model output instead of the more variable two-day output. In a manner similar to Blackford and Gilbert (2007) and Cooley et al. (2012), we define the midpoint of a 10-yr transition period (transition decade) as the point in time when the future envelope of $\mathrm{pH}$ or $\Omega_{\mathrm{arag}}$ diverges from the preindustrial or present-day envelopes. While we report individual years for these transition decades below, it is important to recognize that these years represent the midpoint of $10-\mathrm{yr}$ windows within which these transitions are projected to take place.

Simulations following the SRES A2 emissions scenario show that increasing atmospheric $\mathrm{CO}_{2}$ concentrations cause the $\mathrm{pH}$ and $\Omega_{\text {arag }}$ of the nearshore regions along the US West Coast to move out of their modeled preindustrial and projected present-day variability envelopes before 2050 (Figs. 11 and 12, orange and blue lines). By model year 2011, nearshore waters along the US West Coast have already moved out of the preindustrial envelope. In the northern CCS, pH has only recently departed from the preindustrial variability range due to its large temporal variability (Fig. 11a, upper panel). The fast progression of ocean acidification forces the $\mathrm{pH}$ of the northern subregion to move out of its modeled present-day variability envelope by 2045 , despite the large temporal variability. Surface $\mathrm{pH}$ in the central subregion is projected to depart from its present-day envelope by 2037 (Fig. 11a, center panel). Surface $\Omega_{\text {arag }}$ is projected to move out of its present-day envelope earlier than $\mathrm{pH}$ (Fig. 12a). Already by 2030, the northern CCS is projected to be exposed to lower levels of surface $\Omega_{\text {arag }}$ than experienced in 2011 (Fig. 12a, upper panel). Similarly, surface $\Omega_{\text {arag }}$ of the central subregion will depart from its present-day envelope by 2035 (Fig. 12a, center panel).

By 2023, surface $\mathrm{pH}$ and surface $\Omega_{\mathrm{arag}}$ of the southern subregion are projected to decrease below the range of their relatively small, modeled present-day temporal variability (Figs. 11a and 12a, lower panels). However, these results have to be taken with caution, since our model does not re- produce the large variability observed in the southern CCS. We therefore expect that $\mathrm{pH}$ and $\Omega_{\mathrm{arag}}$ in the southern subregion will remain within their variability envelopes longer than projected by the model (see Sect. 3 and Discussion).

At $100 \mathrm{~m}$ depth, $\mathrm{pH}$ and $\Omega_{\text {arag }}$ of the northern CCS are projected to depart from their modeled present-day variability envelopes by 2033 , while in the central and southern CCS this transition is projected to take place already a decade earlier (Figs. $11 \mathrm{~b}$ and 12b). In addition, permanent undersaturation of $\Omega_{\text {arag }}$ at $100 \mathrm{~m}$ is projected before 2025 in the central and 2035 in the southern and northern CCS.

In a second simulation under which atmospheric $\mathrm{CO}_{2}$ concentrations follow the "low- $\mathrm{CO}_{2}$ " (B1) emissions scenario, surface $\mathrm{pH}$ of the northern subregion is not projected to move out of its present-day envelope before 2050 (see Fig. A2, upper panel). The projected lower atmospheric $\mathrm{CO}_{2}$ concentrations, however, do not affect the timing of transition of $\Omega_{\text {arag }}$ in the north (Fig. A2, upper panel), and $\mathrm{pH}$ and $\Omega_{\text {arag }}$ in the central and southern CCS (Figs. A2a and A3a, center and lower panels). This is because their variability range is low, leading to a departure from their variability envelopes before the atmospheric $p \mathrm{CO}_{2}$ paths of the two emissions scenarios diverge around 2035 (Fig. S5 in Gruber et al., 2012).

The high spatial variations in the temporal variability within each subregion (especially the northern subregion) leads to a large spatial difference in the timing of the transition outside the variability envelope. Figures 13 and 14 illustrate the percentage of overlap between the variability range $\left(\right.$ mean $\left.\pm\left(1 \mathrm{STD} \times v \mathrm{r}_{\mathrm{cf}}\right)\right)$ of a detrended 10-yr period from 2005 to 2015 of $\mathrm{pH}$ and $\Omega_{\mathrm{arag}}$, and the variability range for 10 -yr periods of $\mathrm{pH}$ and $\Omega_{\mathrm{arag}}$ for each following decade. The years 2020, 2030 and 2040 are chosen as midpoints for each 10 -yr period. Nearshore areas, especially in the northern subregion, retain more than $50 \%$ range overlap until 2030 . These areas are exposed to the strongest upwelling and experience the largest range of $\mathrm{pH}$ and $\Omega_{\text {arag }}$ due to the upwelled cold, DIC- and nutrient-rich water. However, areas in the central CCS, south of Monterey Bay $\left(36^{\circ} 48 \mathrm{~N}, 121^{\circ} 54 \mathrm{~W}\right)$, are projected to experience $\mathrm{pH}$ and $\Omega_{\text {arag }}$ values outside of the present-day envelope by 2030 . At $100 \mathrm{~m}$ depth, nearshore areas of the central and southern CCS are projected to be exposed to levels outside of the present-day range by 2020 , while offshore areas retain some degree of overlap of range until 2030. In the northern subregion, the present-day range of $\mathrm{pH}$ and $\Omega_{\mathrm{arag}}$ in nearshore regions still overlap by about $50 \%$ until 2030 .

\subsection{Shoaling of the aragonite saturation horizon}

In the central subregion, the modeled aragonite saturation horizon has already shoaled into the upper $100 \mathrm{~m}$ of the water column and is projected to reach a depth of $50 \mathrm{~m}$ by 2050 (Fig. 15a). The aragonite saturation horizon in the northern and southern CCS are projected to reach a depth of $100 \mathrm{~m}$ by 2025 and shoal to $\sim 70 \mathrm{~m}$ depth by 2050 . Figure $15 \mathrm{~b}$ 


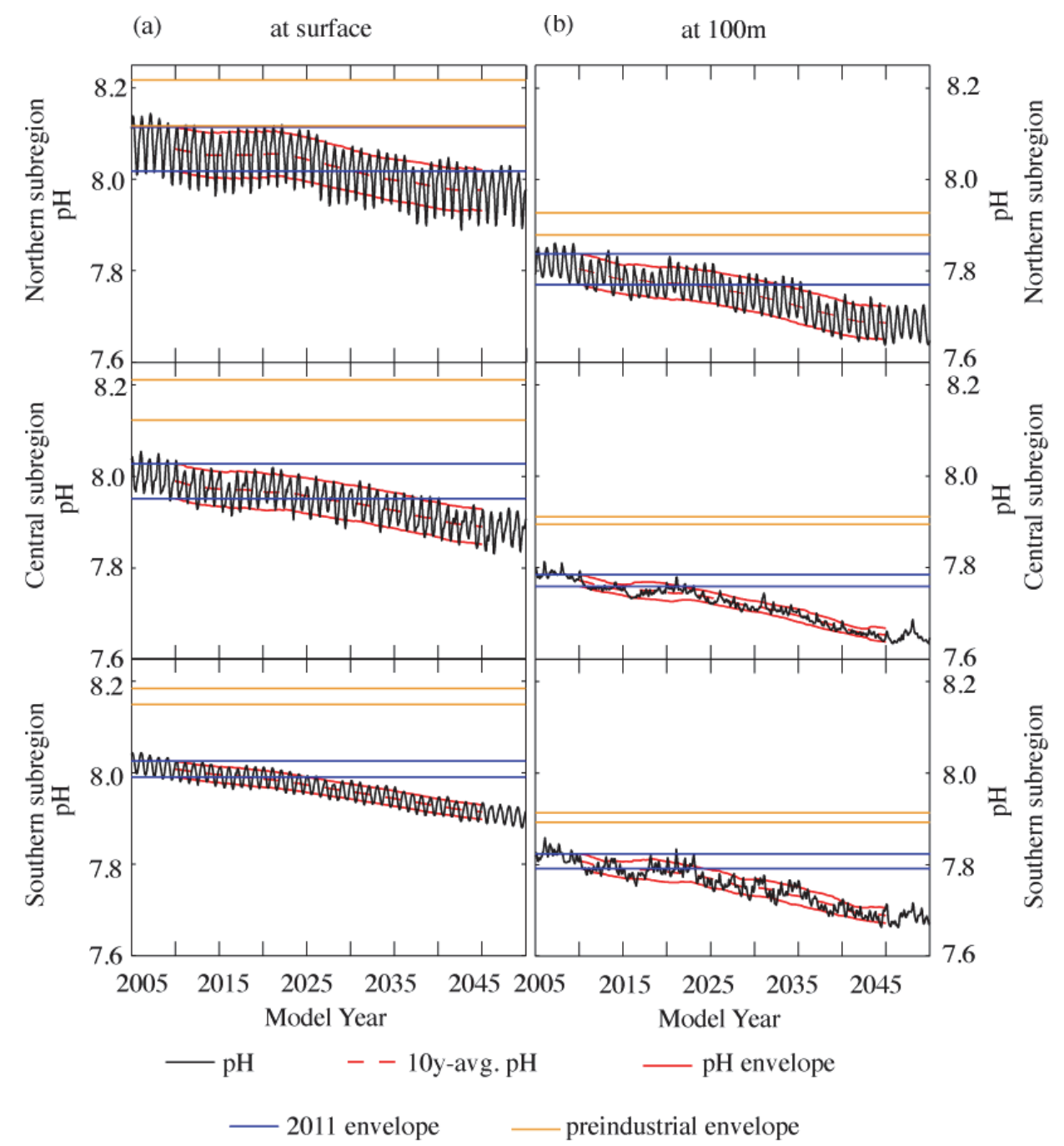

Fig. 11. Simulated time series of monthly mean pH (black) at (a) the surface and (b) $100 \mathrm{~m}$ depth, for the northern (top panel), central (center panel) and southern (bottom panel) subregions, with the 10-yr running average (red dashed line) for all grid cells of each subregion. The area between the solid lines defines the range of annual variability or envelope (mean $\left.\pm\left(1 \mathrm{STD} \times \operatorname{var}_{\mathrm{cf}}\right)\right)$ of $\mathrm{pH}$ for the preindustrial (orange, $\sim 270 \mathrm{ppm}$ atmospheric $p \mathrm{CO}_{2}$ ), 2011 (black, $\sim 395 \mathrm{ppm}$ atmospheric $p \mathrm{CO}_{2}$ ) and transient (red) simulations. The envelopes are adjusted with the correction factor $\operatorname{var}_{\mathrm{cf}}$ (Sect. 2.4).

shows that after reaching the upper $100 \mathrm{~m}$, the shoaling of the aragonite saturation horizon slows down substantially in all subregions. The saturation horizon is highly sensitive to changes in the concentration of $\mathrm{CO}_{3}^{2-}$ where the gradient of $\mathrm{CO}_{3}^{2-}$ concentration with respect to depth is small (Fig. 15). Conversely, when the $\mathrm{CO}_{3}^{2-}$ concentration gradient with respect to depth is strong, the saturation horizon is less sensitive to small changes of $\mathrm{CO}_{3}^{2-}$ concentration. As a result of these sensitivity differences, the aragonite saturation horizon shoals rapidly from 250 to $100 \mathrm{~m}$ because the $\mathrm{CO}_{3}^{2-}$ concentration gradient with respect to depth is small in this depth range. Once the saturation horizon enters the upper $100 \mathrm{~m}$, it requires larger changes in $\mathrm{CO}_{3}^{2-}$ to lead to an equivalent shoaling of the aragonite saturation horizon. This explains why shoaling is initially rapid, and then slows down by about 2025 , when the aragonite saturation horizon enters a depth range with larger gradients in $\mathrm{CO}_{3}^{2-}$ concentration.

\section{Discussion}

The comparison of our model results with the available observations of nearshore carbon properties shows that the model is able to generally reproduce the large-scale spatial and seasonal patterns of contemporary $\mathrm{pH}$ and $\Omega_{\text {arag }}$. However, the following caveats need to be borne in mind while discussing the annual cycle and future trajectories of $\mathrm{pH}$ and $\Omega_{\text {arag }}$ : (1) the model overestimates $\mathrm{pH}$ and $\Omega_{\text {arag }}$ offshore and 


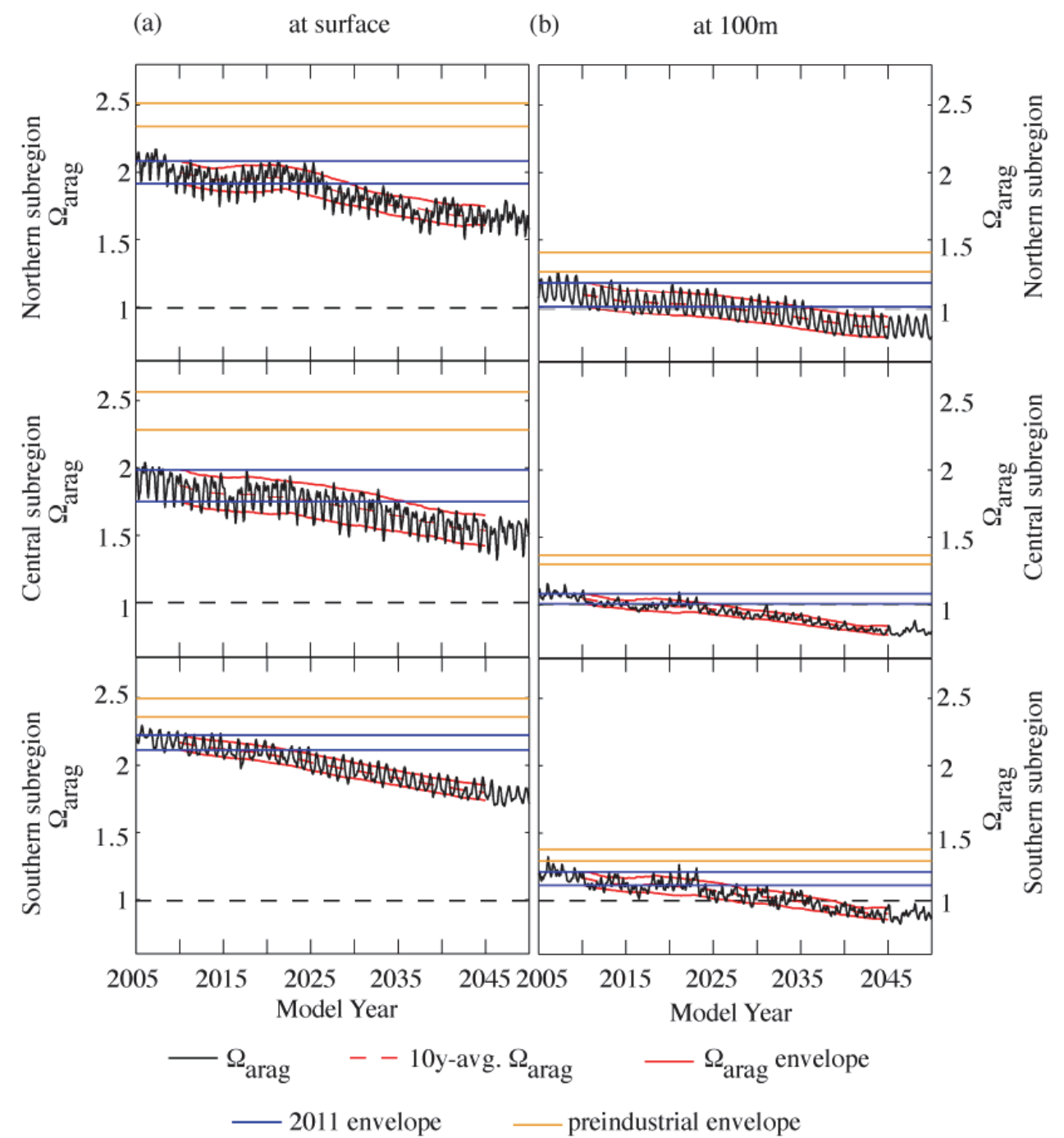

Fig. 12. Simulated time series of monthly mean $\Omega_{\text {arag }}$ (black) at (a) the surface and (b) $100 \mathrm{~m}$ depth, for the northern (top panel), central (center panel) and southern (bottom panel) subregions, with the 10-yr running average (red dashed line) for all grid cells of each subregion. The area between the solid lines defines the range of annual variability or envelope (mean $\left.\pm\left(1 \mathrm{STD} \times \operatorname{var}_{\mathrm{cf}}\right)\right)$ of $\Omega_{\mathrm{arag}}$ for the preindustrial (orange, $\sim 270 \mathrm{ppm}$ atmospheric $p \mathrm{CO}_{2}$ ), 2011 (black, $\sim 395 \mathrm{ppm}$ atmospheric $p \mathrm{CO}_{2}$ ) and transient (red) simulations. The saturation horizon $\left(\Omega_{\text {arag }}=1\right)$ is indicated by the black dashed line. The envelopes are adjusted with the correction factor $\operatorname{var}_{\mathrm{cf}}\left(\mathrm{Sect}_{\mathrm{S}} 2.4\right)$.

at a depth of $100-250 \mathrm{~m}$, and in nearshore regions; (2) the model is forced with monthly climatologies of wind and cannot reproduce weather induced, high-frequency events; (3) the riverine input is not explicitly parameterized; (4) consequences of global change such as changes in $T$, winds or precipitation are not taken into account; (5) interannual processes such as El Niño/La Niña events are not resolved by the model; and (6) ocean acidification-induced changes to important biological processes, such as calcification, photosynthesis and nitrification are not considered by the $\mathrm{NPZD}_{2}$ ecosystem model.
Since the model overestimates $\mathrm{pH}$ and $\Omega_{\text {arag }}$ along the entire US West Coast, the annually averaged depth of the aragonite saturation horizon is about $60 \mathrm{~m}$ shallower in reality. Consequently, we expect that summertime undersaturation of surface waters in nearshore subregions of the northern and central CCS will happen more frequently and with a greater spatial extent than simulated by our model. Comparison to a $\Omega_{\text {arag }}$ time series derived from $\mathrm{O}_{2}$ and $T$ variability emphasizes this bias (Juranek et al., 2009). Between May and November, their statistically modeled present-day aragonite saturation horizon remains within the upper $30 \mathrm{~m}$ of the water column. In contrast, our modeled saturation horizon shoals only occasionally into the upper $30 \mathrm{~m}$ and stays just above 

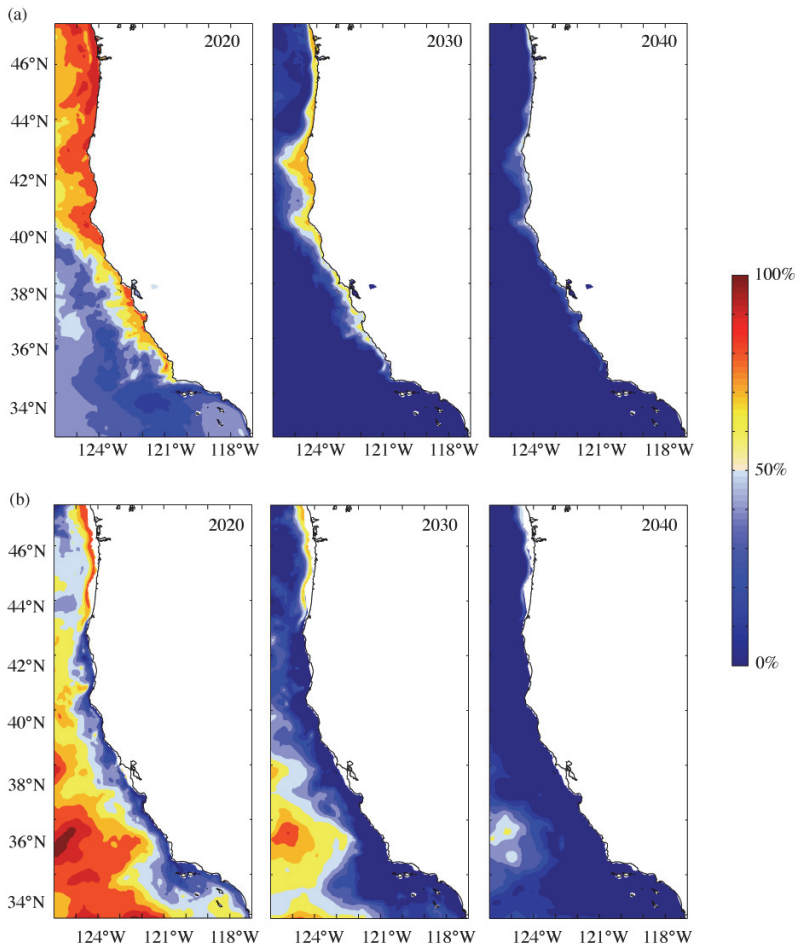
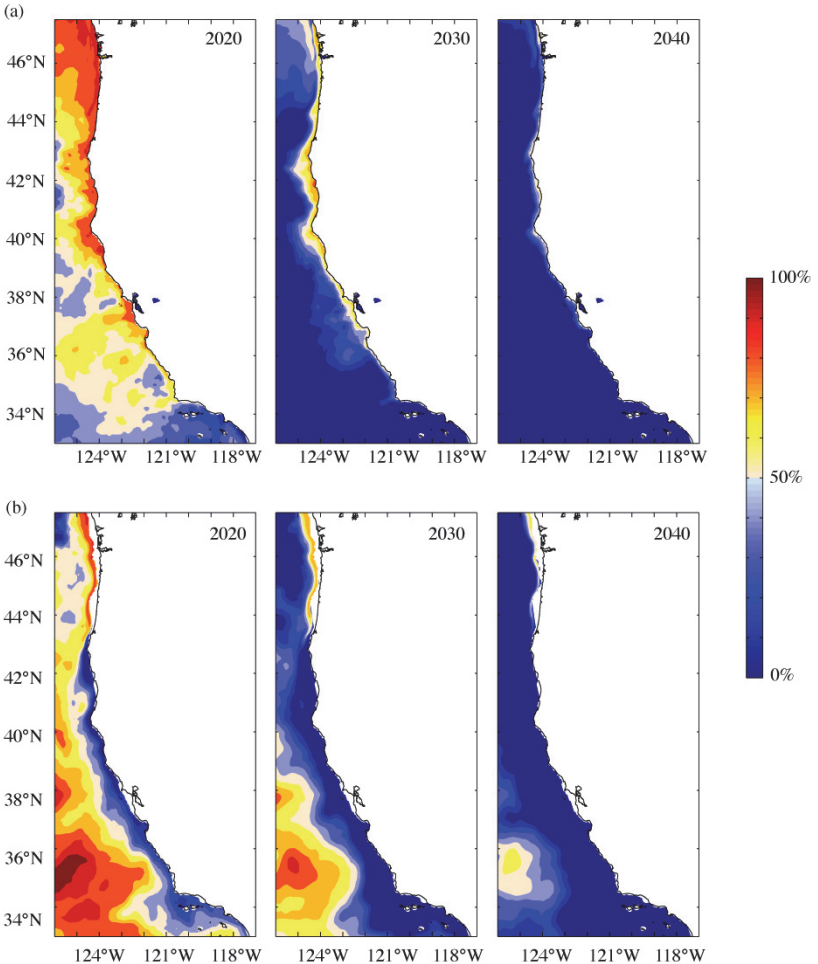

Fig. 13. The proportion of overlap in annual $\mathrm{pH}$ range $\left(\right.$ mean $\left.\pm\left(1 \mathrm{STD} \times \operatorname{var}_{\mathrm{cf}}\right)\right)$ of a 10 -yr average at present for (a) the surface and (b) at $100 \mathrm{~m}$ depth, compared to 10 -yr averages of every following decade until 2040. The years shown are the midpoints of the 10-yr average. The envelopes are adjusted with the correction factor $\operatorname{var}_{\mathrm{cf}}$ (Sect. 2.4).

the central Oregon shelf $(\sim 100 \mathrm{~m})$ during the majority of the upwelling season. The depth bias between the observed and modeled aragonite saturation horizon is expected to decrease with time, because the shoaling of the aragonite saturation horizon is expected to slow down as it approaches shallower depths (see Sect. 4.5).

In our simulations, day-to-day wind variability was not taken into account since the model was forced with a monthly climatology of momentum fluxes from QuickSCAT-based ocean winds. This does not present a large problem in the northern and central subregions where strong seasonal wind patterns prevail (Dorman and Winant, 1995). However, in the southern CCS, synoptic variability dominates (Leinweber et al., 2009; Dorman and Winant, 1995), which is not well captured by our monthly wind climatologies. As a result, the southern subregion is forced with unrealistically smooth wind patterns. Comparison with the SMBO mooring data (Leinweber and Gruber, 2013) underlines this shortcoming of our model for the southern CCS. The model underestimates $\mathrm{pH}$ variability $(1 \mathrm{STD})$ by a factor of $\sim 3.5$. This implies that the projected transition decades would occur about $20 \mathrm{yr}$ later than inferred from our model results. Considering this caveat, the $\mathrm{pH}$ of the southern CCS would move out of

Fig. 14. The proportion of overlap in annual $\Omega_{\text {arag }}$ range $\left(\right.$ mean $\left.\pm\left(1 \mathrm{STD} \times \mathrm{var}_{\mathrm{cf}}\right)\right)$ of a 10 -yr average at present for $(\mathbf{a})$ the surface and (b) at $100 \mathrm{~m}$ depth, compared to 10 -yr averages of every following decade until 2040 . The years shown are the midpoints of the 10-yr average. The envelopes are adjusted with the correction factor $\operatorname{var}_{\mathrm{cf}}$ (Sect. 2.4).

its preindustrial envelope around 2020 and depart from the present-day levels shortly after 2050 . The temporal variability of surface $\Omega_{\mathrm{arag}}$ is underestimated in the model by a factor of $\sim 7$ at the SMBO mooring, implying that the southern subregion will likely not move out of its preindustrial envelope before 2050. The comparison with observational data derived from the recently deployed mooring off Newport, Oregon (Harris et al., 2013, see Sect. 3) and reconstructed pH and $\Omega_{\text {arag }}$ from $T$ and $\mathrm{O}_{2}$ time series (Alin et al., 2012) indicate that our modeled size of the variability envelopes is in better agreement with the limited available data in the northern and central CCS than they are in the southern subregion. Taking advantage of the fast-growing US carbon mooring network in the future will help to further constrain the model bias and better predict the present-day variability envelope. Forcing the model with wind products at daily or higher temporal resolution could help to better simulate the observed high temporal variability in the winds and sporadic, strong upwelling events that cause extremely low levels of $\mathrm{pH}$ and $\Omega_{\mathrm{arag}}$.

Riverine input of nutrients, DIC and freshwater can increase the range of $\mathrm{pH}$ variability by up to about 1 unit (Hinga, 2002). Since the riverine input is not explicitly 


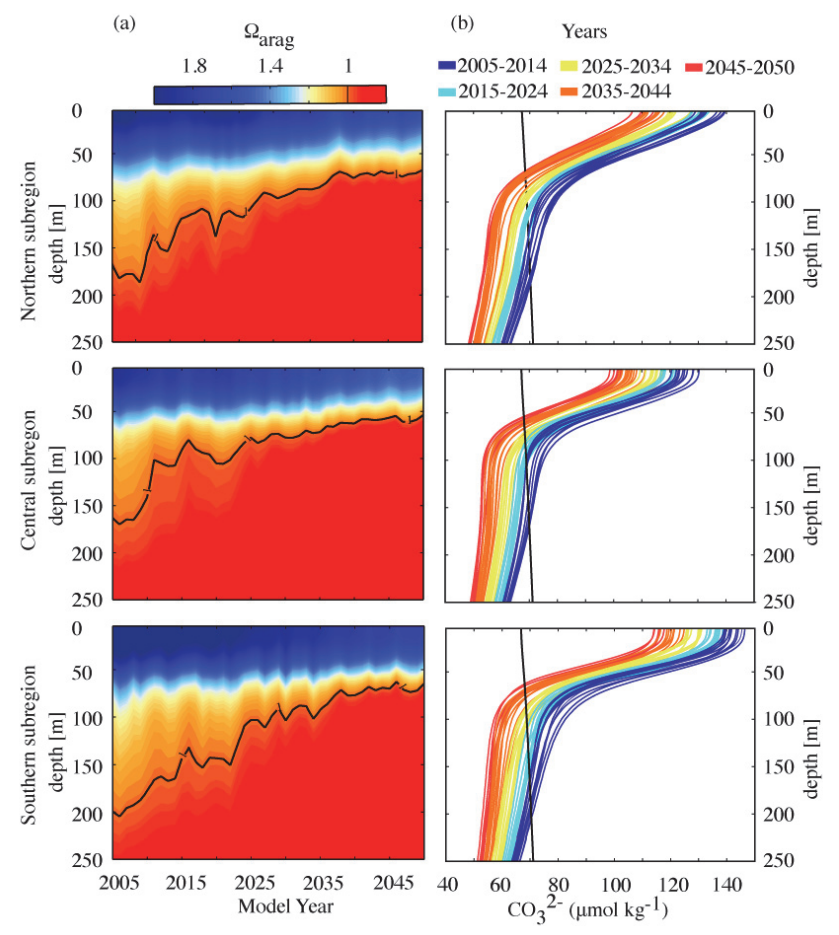

Fig. 15. (a) Evolution of the depth of aragonite saturation horizon as a function of time and depth. The depth of the saturation horizon is depicted as a black line. Panel (b) shows the expected shifts in the $\left[\mathrm{CO}_{3}^{2-}\right]$ profiles for the years $2005-2050$. The black line indicates the depth of the saturation horizon as a function of $\left[\mathrm{CO}_{3}^{2-}\right]$ and depth.

modeled in this study, $\mathrm{pH}$ and $\Omega_{\text {arag }}$ may not be accurately represented in close proximity to the Columbia River mouth, especially during the rainy months (February-June). Other small rivers along the coast can influence DIC and Alk, but their influence is likely small and often limited to infrequent storm events. The surface $T$ and $S$ restoring described in Sect. 2 improves the mean state, but does not capture the natural variability.

Our study accounted for changes of $\mathrm{pH}$ and $\Omega_{\text {arag }}$ due to atmospheric $p \mathrm{CO}_{2}$ increase. However, additional consequences of the anthropogenic $p \mathrm{CO}_{2}$ increase through its effects on the Earth's radiation balance were not taken into account. These include changes in upwelling intensity, strengthened stratification, warming of surface waters, the deepening of the thermocline (King et al., 2011) and thus potential changes in the seasonal cycle. Integrated effects of global change could possibly accelerate the progression of ocean acidification described here. For example, a time series (1982-2008) of upwelling favorable winds and sea surface $T$ suggests that a strengthening of large-scale pressure gradient fields led to increased and protracted upwelling in parts of the central CCS (García-Reyes and Largier, 2010), which in turn would lead to lower surface $\mathrm{pH}$ and $\Omega_{\mathrm{arag}}$, further exacerbating the effects of increasing $p \mathrm{CO}_{2}$ on the CCS. In addition to increased aragonite undersaturation, shoaling of low oxygen waters further minimizes habitats of sensitive organisms (Bograd et al., 2008; McClatchie et al., 2010). Oxygen declines in the CCS result from decreasing concentrations of oxygen in the Equatorial and Eastern Pacific (Stramma et al., 2008, 2010; Bograd et al., 2008). These oxygen declines are thought to be due to increased stratification resulting from global warming (Stramma et al., 2008). As a result of continued global warming and intensified upwelling, hypoxic areas are expected to further expand in the CCS in the future.

The dynamics of the CCS is strongly modified by interannual to decadal climate modes such as El Niño/La Niña events or the Pacific Decadal Oscillation, which are not resolved by our model. The La Niña event in 2010 uplifted the isopycnals in late summer and doubled the period of normal seasonal exposure to undersaturated conditions on the continental shelf off California (Nam et al., 2011). The season of occurrence of La Niña events is variable. It is therefore possible that La Niña amplifies the effect of natural seasonal upwelling, leading to more extreme hypoxic and aragonite undersaturated conditions. As a result, variability envelopes would be widened and the transitions toward the conditions outside these envelopes would be delayed, while seasonal aragonite undersaturation would occur earlier.

Ocean acidification may trigger several physiological responses in organisms, some of which may lead to significant changes in the DIC and Alk concentrations. However, none of these potential responses are represented in our simple $\mathrm{NPZD}_{2}$ ecosystem model. Ongoing research suggests that several biological processes can be affected by ocean acidification (reviewed in e.g., Doney et al. 2009) with calcification likely being the most relevant. Coccolithophores as the dominant calcifiers show a wide range of responses in their calcification rates to ocean acidification (e.g., Riebesell et al., 2000; Langer et al., 2006; Iglesias-Rodriguez et al., 2008), with possible effects on the vertical distribution of Alk (Ilyina et al., 2009). Here, calcium carbonate formation was kept at a fixed rate, introducing additional uncertainty to the study. But given the limited importance of calcification in controlling $\mathrm{pH}$ and $\Omega_{\text {arag }}$ in the CCS, we consider the potential impact of changes in calcification on our results to be relatively limited.

We found that the CCS is approaching the combined thresholds of both chemical aragonite dissolution and the departure from its variability envelope with respect to $\mathrm{pH}$

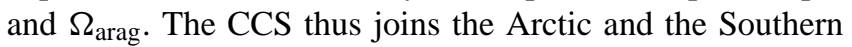
oceans as one of only a few known ocean regions presently approaching this dual threshold (Steinacher et al., 2009; McNeil and Matear, 2008). Therefore, organisms in these regions must adapt to conditions that are both inherently chemically challenging and significantly different from present conditions. In contrast, while locations such as ocean station ALOHA are projected to depart their variability envelope by 2020 (Cooley et al., 2012), the inherent chemical properties at these sites leave them far from aragonite undersaturation. 


\section{Conclusions}

This study gives new insights into the spatial and temporal dynamics of $\mathrm{pH}$ and $\Omega_{\mathrm{arag}}$ along the US West Coast. It further enables us to relate the present-day high spatial and temporal variability of $\mathrm{pH}$ and $\Omega_{\text {arag }}$ to their modeled preindustrial and projected future ranges of $\mathrm{pH}$ and $\Omega_{\mathrm{arag}}$. While a few nearshore areas of the central and northern subregions are presently exposed to temporary undersaturation, our results also highlight the fact that the nearshore ecosystems along the US West Coast are already exposed to $\mathrm{pH}$ and $\Omega_{\text {arag }}$ levels outside of the modeled preindustrial variability envelope. Additionally, as early as $\sim 2040$, surface $\mathrm{pH}$ and $\Omega_{\text {arag }}$ of the nearshore US West Coast are projected to move out of the modeled present-day variability envelope under increasing atmospheric $\mathrm{CO}_{2}$ concentrations as projected from the IPCC SRES A2-Scenario.

The combination of naturally high DIC and the oceanic uptake of anthropogenic $\mathrm{CO}_{2}$ drives the $\mathrm{CCS}$ toward undersaturation faster than other coastal areas (Blackford and Gilbert, 2007) and on a similar timescale as the Arctic and Southern oceans (Gruber et al., 2012). Despite the high annual variability, the absolute decrease of $\mathrm{pH}$ and $\Omega_{\text {arag }}$ is fast and significant enough to cause a departure from its presentday range by 2040 . We conclude that these types of changes put the CCS particularly at risk to the effects of ocean acidification. Given the imminent departure from preindustrial envelopes, we speculate that these effects may already be well underway.

Marine ecosystems of the CCS are exposed to a variety of stress factors, many of which are projected to increase in the future. Along with the developing problem of ocean acidification, organisms will have to deal with warming of the waters, an expansion of hypoxic areas and changes of the vertical structure of the water column (Gruber, 2011; Doney et al., 2012). Furthermore, non-climate change-related impacts, such as pollution, eutrophication and overfishing further increase the vulnerability of the CCS ecosystems. Together, these stressors compound the challenges that many organisms of the CCS will face in the coming decades and will necessitate rapid migration, acclimation or adaptation in order to cope with these changing environmental conditions.

\section{Appendix A}

\section{Description of the carbon biogeochemistry module}

The carbon biogeochemistry module adds the three new state variables DIC, Alk and $\mathrm{CaCO}_{3}\left(D_{\mathrm{CaCO}_{3}}\right)$ to the model. The conservation equation for any tracer concentration $B$ is given by

$$
\begin{aligned}
\frac{\partial B}{\partial t} & =\underbrace{\nabla \cdot \mathbf{K} \nabla B}_{\text {diffusion }}-\underbrace{\boldsymbol{u} \cdot \nabla_{\mathrm{h}} B}_{\text {horiz. advection }}-\underbrace{\left(w+w^{\text {sink }}\right) \frac{\partial B}{\partial z}}_{\text {vert. advection \& sinking }} \\
& +\underbrace{J(B)}_{\text {source minus sink term }},
\end{aligned}
$$

where $\mathbf{K}$ is the eddy kinematic diffusivity tensor, $\nabla$ is the 3-D gradient, $\nabla_{\mathrm{h}}$ is the horizontal gradient, $\boldsymbol{u}$ denotes the horizontal and $w$ the vertical velocities of the fluid, and $w^{\text {sink }}$ is the vertical sinking rate of all particulate pools, except zooplankton (see Table A1). $J(B)$ denotes the source minus sink term for each tracer, which is described in detail for DIC, Alk and $D_{\mathrm{CaCO}_{3}}$ in the following. The remaining source minus sink terms for the other model state variables are defined in Gruber et al. (2006).

The sources and sinks of DIC include net community production, gas exchange, and $\mathrm{CaCO}_{3}$ formation and dissolution:

$$
\begin{aligned}
& J(\mathrm{DIC})=-\underbrace{\mu_{P}^{\max }(T, I) \cdot \gamma\left(\mathrm{NO}_{3}^{-}, \mathrm{NH}_{4}^{+}\right) \cdot P \cdot r_{\mathrm{C}: \mathrm{N}}}_{\text {net primary production }} \\
& -\underbrace{k_{\mathrm{CaCO}_{3}}^{\mathrm{form}} \cdot \mu_{P}^{\max }(T, I) \cdot \gamma\left(\mathrm{NO}_{3}^{-}, \mathrm{NH}_{4}^{+}\right) \cdot P \cdot r_{\mathrm{C}: \mathrm{N}}}_{\mathrm{CaCO}_{3} \text { formation }} \\
& +\underbrace{k_{D_{\mathrm{S}}}^{\text {remin }} D_{\mathrm{S}} \cdot r_{\mathrm{C}: \mathrm{N}}+k_{D_{\mathrm{L}}}^{\text {remin }} D_{\mathrm{L}} \cdot r_{\mathrm{C}: \mathrm{N}}}_{\text {detritus remineralization }} \\
& +\underbrace{\eta_{Z}^{\text {metab }} Z \cdot r_{\mathrm{C}: \mathrm{N}}}_{\text {zooplankton respiration }}+\underbrace{k_{\mathrm{CaCO}_{3}}^{\text {diss }} D_{\mathrm{CaCO}_{3}}}_{\text {dissolution }} \\
& +\underbrace{k_{S_{D}}^{\text {remin }} S_{D} \cdot r_{\mathrm{C}: \mathrm{N}}}_{\text {sediment remineralization at } k=1} \\
& +\underbrace{k_{S_{\mathrm{CaCO}_{3}}}^{\text {diss }} S_{\mathrm{CaCO}_{3}} \cdot r_{\mathrm{C}: \mathrm{N}}}_{\text {sediment dissolution at } k=1}+\underbrace{J_{\mathrm{Gas}}}_{\text {gas exchange }} .
\end{aligned}
$$

This equation follows the nomenclature used in Gruber et al. (2006). Symbols with parentheses, such as $\mu_{P}^{\max }(T, I)$ represent functions of the respective variables. $J^{\text {Gas }}$ is the gas exchange flux described below (Eq. A3). The state variable associated with the function/parameter is denoted in the subscript, while the corresponding process is given in the superscript. The variables in the equation denote the following: $I$ and $T$ are light and temperature, respectively, $P$ is the phytoplankton pool, $Z$ is the zooplankton pool, $D_{\mathrm{S}}$ is the small detritus pool, $D_{\mathrm{L}}$ is the large detritus pool, $D_{\mathrm{CaCO}_{3}}$ is the $\mathrm{CaCO}_{3}$ pool in the water column, $S_{D}$ is the nitrogen and $S_{\mathrm{CaCO}_{3}}$ is the $\mathrm{CaCO}_{3}$ pool in the sediment. All relevant parameters are described in Table A1. The carbon fluxes are tied to those of nitrogen with a fixed stoichiometric ratio $r_{\mathrm{C}: \mathrm{N}}$ of $106: 16$ (Redfield et al., 1963).

Net primary production is the sum of regenerated and new production and decreases the DIC pool. Depending on 
Table A1. Summary of the definitions, symbols, values and units of the parameters used in the carbon module of the ecologicalbiogeochemical model.

\begin{tabular}{|c|c|c|c|}
\hline Parameter & Symbol & Value & Units \\
\hline Carbon to nitrogen ratio of organic matter & $r_{\mathrm{C}: \mathrm{N}}$ & 6.25 & - \\
\hline \multicolumn{4}{|l|}{ Remineralization and respiration parameters } \\
\hline $\begin{array}{l}\text { Remineralization rate of } D_{\mathrm{S}} \\
\text { Remineralization rate of } D_{\mathrm{L}} \\
\text { Zooplankton basal metabolism rate }\end{array}$ & $\begin{array}{l}k_{D_{\mathrm{S}}}^{\text {remin }} \\
k_{D_{\mathrm{L}}}^{\text {remin }} \\
\eta_{Z}^{\text {metab }}\end{array}$ & $\begin{array}{l}0.03 \\
0.01 \\
0.1\end{array}$ & $\begin{array}{l}\text { day }^{-1} \\
\text { day }^{-1} \\
\text { day }^{-1}\end{array}$ \\
\hline \multicolumn{4}{|l|}{$\mathrm{CaCO}_{3}$ formation and dissolution parameters } \\
\hline $\begin{array}{l}\mathrm{CaCO}_{3} \text { fraction of net primary production } \\
\mathrm{CaCO}_{3} \text { dissolution rate }\end{array}$ & $\begin{array}{l}k_{\mathrm{CaCO}_{3}}^{\text {form }} \\
k_{\mathrm{CaCO}}^{\mathrm{diss}} \\
\end{array}$ & $\begin{array}{l}0.07 \\
0.0057\end{array}$ & $\begin{array}{l}- \\
\text { day }^{-1}\end{array}$ \\
\hline \multicolumn{4}{|l|}{ Sediment parameters } \\
\hline $\begin{array}{l}\text { Sediment remineralization of organic matter } \\
\text { Sediment dissolution of } \mathrm{CaCO}_{3}\end{array}$ & $\begin{array}{l}k_{S_{D}}^{\text {remin }} \\
k_{S_{\mathrm{CaCO}}}^{\text {diss }}\end{array}$ & $\begin{array}{l}0.003 \\
0.002\end{array}$ & $\begin{array}{l}\text { day }^{-1} \\
\text { day }^{-1}\end{array}$ \\
\hline \multicolumn{4}{|l|}{ Sinking parameters } \\
\hline $\begin{array}{l}\text { Sinking velocity of } P \\
\text { Sinking velocity of } D_{\mathrm{S}} \\
\text { Sinking velocity of } D_{\mathrm{L}} \\
\text { Sinking velocity of } D_{\mathrm{CaCO}_{3}}\end{array}$ & $\begin{array}{l}w_{P}^{\operatorname{sink}} \\
w_{D_{\mathrm{S}}}^{\operatorname{sink}} \\
w_{D_{\mathrm{L}}}^{\text {sink }} \\
w_{D_{\mathrm{CaCO}_{3}}}^{\text {sink }}\end{array}$ & $\begin{array}{l}0.5 \\
1.0 \\
10.0 \\
20.0\end{array}$ & $\begin{array}{l}\text { m day }^{-1} \\
\text { mday }^{-1} \\
\text { m day }^{-1} \\
\text { m day }^{-1}\end{array}$ \\
\hline
\end{tabular}

whether phytoplankton $(P)$ take up $\mathrm{NH}_{4}^{+}$or $\mathrm{NO}_{3}^{-}$, nitrogen adds to either the regenerated or the new production flux, respectively. The modeled phytoplankton growth is limited by temperature $(T)$, light $(I)$ and the concentrations of $\mathrm{NO}_{3}^{-}$and $\mathrm{NH}_{4}^{+} \cdot \mu_{P}^{\max }(T, I)$ is the temperature-dependent, light-limited growth rate of $P$ under nutrient replete condition. $\gamma\left(\mathrm{NO}_{3}^{-}\right.$, $\mathrm{NH}_{4}^{+}$) is a non-dimensional nutrient limitation factor, with a stronger limitation for nitrate than ammonium, taking into account that $P$ take up $\mathrm{NH}_{4}^{+}$preferentially over $\mathrm{NO}_{3}^{-}$and that the presence of ammonium inhibits the uptake of nitrate by $P$. For a more detailed description of these limitation factors the reader is referred to Gruber et al. (2006).

Formation of $D_{\mathrm{CaCO}_{3}}$ also decreases the DIC pool and is parameterized as $7 \%$ of the net primary production, such that for each mole of organic carbon formed by net primary production, $0.07 \mathrm{~mol}$ of $D_{\mathrm{CaCO}_{3}}$ are formed. $D_{\mathrm{CaCO}_{3}}$ dissolves at a fixed first order rate of $0.0057 \mathrm{day}^{-1}$. This process releases $\mathrm{CO}_{3}^{2-}$, and thus adds to the DIC pool. The full source minus sink equation for $D_{\mathrm{CaCO}_{3}}$ is described below (Eq. A6).

Zooplankton $(Z)$ are parameterized with one size class (mesozooplankton). The $Z$ respiration from basal metabolism and remineralization processes increases the total DIC pool. Large detritus $\left(D_{\mathrm{L}}\right)$ is remineralized at a rate of $0.01 \mathrm{mday}^{-1}$ and small detritus $\left(D_{\mathrm{S}}\right)$ at a rate of $0.03 \mathrm{~m} \mathrm{day}^{-1}$. The different sinking speeds and remineralization rates of small and large detritus result in a large difference of the remineralization length scales of $30 \mathrm{~m}$ for $D_{\mathrm{S}}$ and
$1000 \mathrm{~m}$ for $D_{\mathrm{L}}$. As a consequence, $D_{\mathrm{L}}$ is rapidly transported to depths below the euphotic zone, while $D_{\mathrm{S}}$ is subjected to offshore transport and is absent in the ocean interior (Gruber et al., 2006).

The sediment is parameterized as a simple one layer model added to the bottom layer $(k=1)$ of the model. The sediment is represented by the state variables $S_{D}\left(\mathrm{mmol} \mathrm{N} \mathrm{m}^{-2}\right)$ and $S_{\mathrm{CaCO}_{3}}\left(\mathrm{mmol} \mathrm{C} \mathrm{m}^{-2}\right)$. Once organic matter and $\mathrm{CaCO}_{3}$ arrive at the sediment surface they are accumulated in the sediment layer. The accumulated organic matter and $\mathrm{CaCO}_{3}$ are subjected to first-order decomposition reactions that release dissolved material into the deepest model layer $k=1$ and thus back into the water column.

Gas exchange is parameterized following Wanninkhof (1992):

$J^{\mathrm{Gas}}=\mathrm{CO}_{2}^{\mathrm{sol}} \cdot k \cdot\left(p \mathrm{CO}_{2}^{\mathrm{air}}-p \mathrm{CO}_{2}^{\text {ocean }}\right)$,

where

$k=0.31 \cdot u^{2}(S c / 660)^{-1 / 2}$.

$\mathrm{CO}_{2}^{\text {sol }}$ is the temperature and salinity dependent solubility of $\mathrm{CO}_{2}, p \mathrm{CO}_{2}$ air is the $\mathrm{CO}_{2}$ partial pressure in the atmosphere and $p \mathrm{CO}_{2}{ }^{\text {ocean }}$ is the partial pressure of $\mathrm{CO}_{2}$ in seawater. Oceanic uptake of $\mathrm{CO}_{2}$ increases DIC, while it does not influence Alk. Oceanic $p \mathrm{CO}_{2}$ is calculated from DIC, Alk, temperature and salinity using the standard OCMIP carbonate 
Table A2. Evaluation of model with regard to its spatial variability: Shown are the normalized model standard deviation (norm. STD.), the correlation coefficient and bias of observed and modeled $\mathrm{pH}$, $\Omega_{\text {arag }}$, Alkalinity, DIC, Temperature and Salinity. A five-year average of modeled parameters over May and June (2006-2010) are compared to observations sampled between May and June 2007 (Feely et al., 2008), for all sampled locations (CCS), the subregions north, central, southern, for 0-100 m, 100-250 m and 500-5000 m. The modeled standard deviations were normalized relative to the observed standard deviations from Feely et al. (2008). Specified units correspond only to the absolute bias.

\begin{tabular}{|c|c|c|c|c|}
\hline Property & Location & $\begin{array}{l}\text { norm. } \\
\text { STD }\end{array}$ & $\begin{array}{l}\text { Correlation } \\
\text { coefficient }\end{array}$ & $\begin{array}{l}\text { Absolute } \\
\text { bias }\end{array}$ \\
\hline \multirow{7}{*}{$\mathrm{pH}$} & CCS & 0.74 & 0.89 & -0.06 \\
\hline & northern & 0.73 & 0.91 & -0.07 \\
\hline & central & 0.76 & 0.89 & -0.05 \\
\hline & southern & 0.71 & 0.89 & -0.07 \\
\hline & $0-100 \mathrm{~m}$ & 0.58 & 0.74 & -0.04 \\
\hline & $100-250 \mathrm{~m}$ & 0.33 & 0.43 & -0.10 \\
\hline & $250-4500 \mathrm{~m}$ & 0.91 & 0.68 & -0.09 \\
\hline \multirow{7}{*}{$\Omega$ Aragonite } & CCS & 0.83 & 0.89 & -0.11 \\
\hline & northern & 0.79 & 0.91 & -0.11 \\
\hline & central & 0.87 & 0.89 & -0.09 \\
\hline & southern & 0.82 & 0.88 & -0.12 \\
\hline & $0-100 \mathrm{~m}$ & 0.64 & 0.74 & -0.08 \\
\hline & $100-250 \mathrm{~m}$ & 0.52 & 0.58 & -0.15 \\
\hline & $250-4500 \mathrm{~m}$ & 1.37 & 0.83 & -0.11 \\
\hline \multirow{7}{*}{$\begin{array}{l}\text { Alkalinity } \\
\left(\mu \mathrm{mol} \mathrm{kg}^{-1}\right)\end{array}$} & CCS & 0.88 & 0.92 & -6 \\
\hline & northern & 0.77 & 0.93 & -20 \\
\hline & central & 0.95 & 0.92 & -4 \\
\hline & southern & 1.04 & 0.94 & -1 \\
\hline & $0-100 \mathrm{~m}$ & 0.40 & 0.79 & -6 \\
\hline & $100-250 \mathrm{~m}$ & 0.63 & 0.68 & -6 \\
\hline & $250-4500 \mathrm{~m}$ & 0.99 & 0.99 & -8 \\
\hline \multirow{7}{*}{$\begin{array}{l}\text { DIC } \\
\left(\mu \mathrm{mol} \mathrm{kg}{ }^{-1}\right)\end{array}$} & CCS & 0.87 & 0.92 & 14 \\
\hline & northern & 0.79 & 0.93 & 3 \\
\hline & central & 0.91 & 0.92 & 12 \\
\hline & southern & 0.91 & 0.93 & 21 \\
\hline & $0-100 \mathrm{~m}$ & 0.56 & 0.77 & 10 \\
\hline & $100-250 \mathrm{~m}$ & 0.57 & 0.69 & 22 \\
\hline & $250-4500 \mathrm{~m}$ & 1.21 & 0.98 & 13 \\
\hline \multirow{7}{*}{$\begin{array}{l}\text { Temperature } \\
\left(\mathrm{C}^{\circ}\right)\end{array}$} & CCS & 1.15 & 0.95 & -0.31 \\
\hline & northern & 1.05 & 0.95 & -0.03 \\
\hline & central & 1.15 & 0.93 & -0.31 \\
\hline & southern & 1.18 & 0.95 & -0.47 \\
\hline & $0-100 \mathrm{~m}$ & 0.97 & 0.85 & -0.90 \\
\hline & $100-250 \mathrm{~m}$ & 1.13 & 0.88 & 0.40 \\
\hline & $250-4500 \mathrm{~m}$ & 0.87 & 0.99 & 0.44 \\
\hline \multirow{7}{*}{$\begin{array}{l}\text { Salinity } \\
\text { (PSU) }\end{array}$} & CCS & 0.78 & 0.86 & 0.18 \\
\hline & northern & 0.69 & 0.88 & 0.004 \\
\hline & central & 0.91 & 0.83 & 0.20 \\
\hline & southern & 1.14 & 0.86 & 0.26 \\
\hline & $0-100 \mathrm{~m}$ & 0.50 & 0.87 & 0.21 \\
\hline & $100-250 \mathrm{~m}$ & 0.88 & 0.71 & 0.22 \\
\hline & $250-4500 \mathrm{~m}$ & 1.08 & 0.90 & 0.04 \\
\hline
\end{tabular}

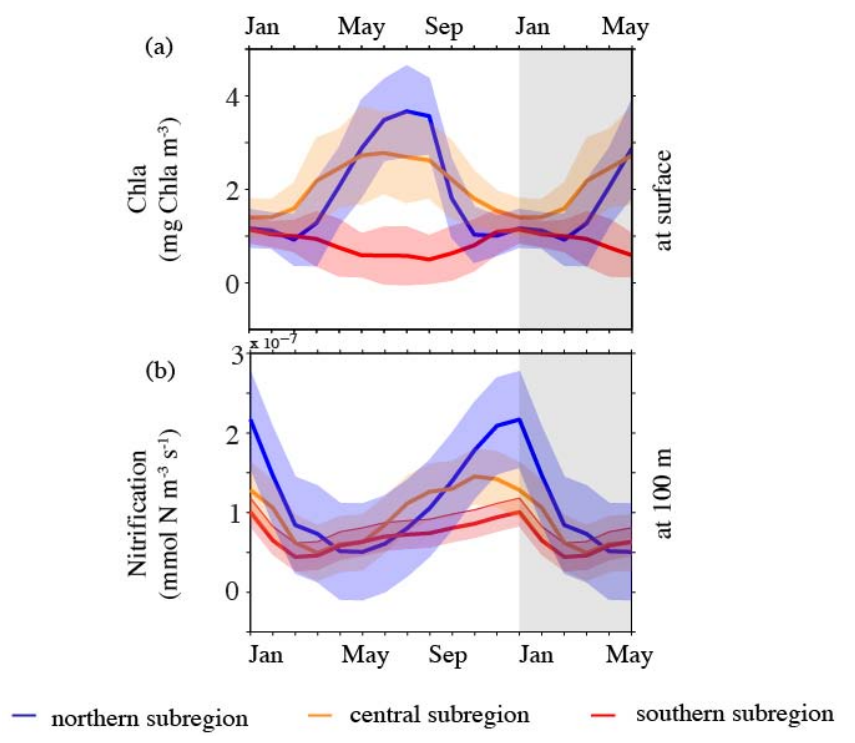

Fig. A1. Seasonal cycle of (a) surface chlorophyll $a$ and (b) nitrification at $100 \mathrm{~m}$, in the nearshore $50 \mathrm{~km}$. The lines represent the mean and the shaded area the spatial variability ( \pm 1 STD) for each month, for the northern (blue), central (orange) and southern (red) subregions. The shaded area depicts the first six months of the following annual cycle.

chemistry routines ${ }^{3}$. The routines used the carbonic acid dissociation constants of Mehrbach et al. (1973), as refit by Dickson and Millero (1987) and Dickson (1990). The pressure effect on the solubility was estimated from the equation of Mucci (1983), including the adjustments to the constants recommended by Millero (1995). $k$ is the gas transfer coefficient given by equation three in Wanninkhof (1992), which is dependent on the square of the instantaneous wind speed $(u)$ and the temperature dependent Schmidt number $(S c)$.

Alk increases due to the removal of $\mathrm{NO}_{3}^{-}$(new production) and dissolution of $\mathrm{CaCO}_{3}$ and decreases due to the formation of $\mathrm{NO}_{3}^{-}$(nitrification) and formation of $\mathrm{CaCO}_{3}$ :

$$
\begin{aligned}
J(\mathrm{Alk})= & +\underbrace{2 \cdot k_{\mathrm{CaCO}_{3}}^{\text {diss }} D_{\mathrm{CaCO}_{3}}}_{\text {dissolution }} \\
& +\underbrace{\mu_{P}^{\max }(T, I) \cdot \gamma\left(\mathrm{NO}_{3}^{-}\right) \cdot P \cdot r_{\mathrm{C}: \mathrm{N}}}_{\text {new production }} \\
& +\underbrace{2 \cdot k_{\mathrm{CaCO}_{3}}^{\text {diss } S_{\mathrm{CaCO}_{3}}}}_{\text {sediment dissolution at } k=1} \\
& -\underbrace{2 \cdot k_{\mathrm{CaCO}}^{\text {form }} \cdot \mu_{P}^{\text {max }}(T, I) \cdot \gamma\left(\mathrm{NO}_{3}^{-}, \mathrm{NH}_{4}^{+}\right) \cdot P \cdot r_{\mathrm{C}: \mathrm{N}}}_{\text {nitrification }}
\end{aligned}
$$

\footnotetext{
${ }^{3}$ http://ocmip5.ipsl.jussieu.fr/OCMIP/
} 


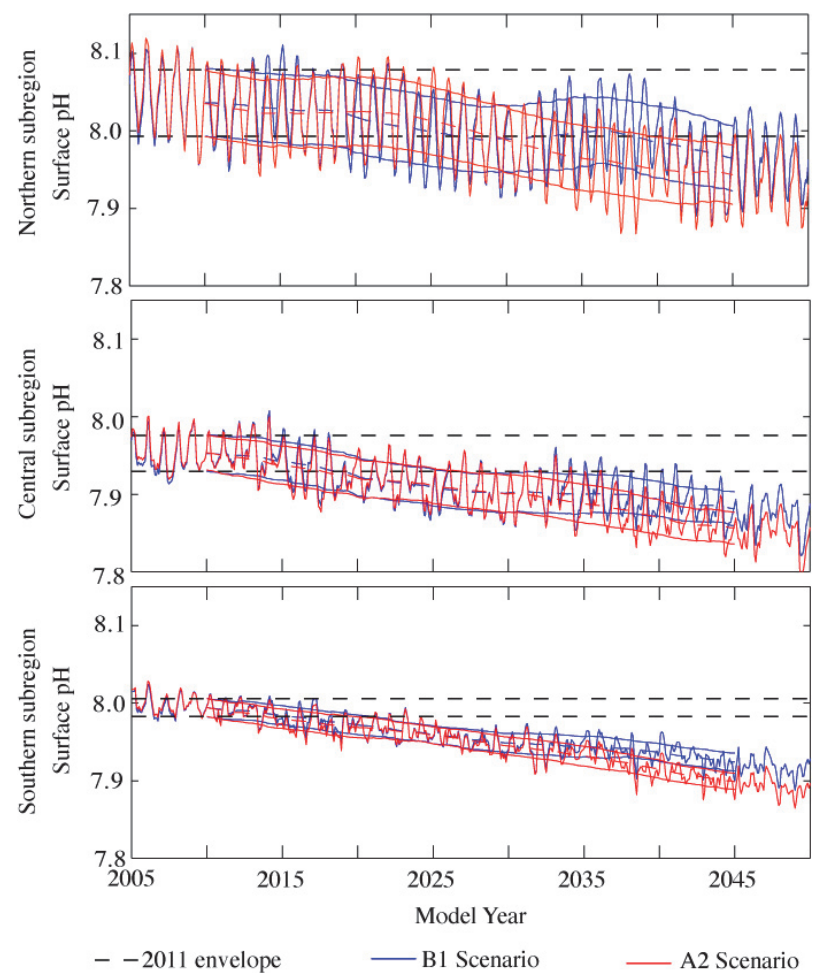

Fig. A2. Simulated time series of monthly mean surface $\mathrm{pH}$ for the two employed IPCC-SRES scenarios A2 (red) and B1 (blue), for the northern (top panel), central (center panel) and southern (bottom panel) subregions, with the 10-yr running average (dashed red and blue lines) of the mean for all grid cells of each subregion. The area between the solid lines defines the range of annual variability or envelope (mean \pm 1 STD) of $\mathrm{pH}$ for 2011 (black, $\sim 395 \mathrm{ppm}$ atmospheric $p \mathrm{CO}_{2}$ ) and the transient simulations following the $\mathrm{A} 2$ (red) and B2 (blue) emissions scenarios. The results are based on simulations with the $15-\mathrm{km}$ resolution set-up.

Nitrification is light-limited $(I)$ and parameterized at a rate of 0.05 day $^{-1}$ (see Gruber et al., 2006). $\mathrm{CaCO}_{3}$ formation and dissolution processes change Alk twice as much as DIC. This can be explained from the definition of alkalinity (Dickson, 1981) where the addition (removal) of $1 \mathrm{~mol}$ of $\mathrm{CO}_{3}^{2-}$ results in a 2 mol change in Alk.

The concentration of $\mathrm{CaCO}_{3}\left(\mathrm{mmolCm}^{-3}\right)$ is dependent on net primary production and dissolution:

$$
\begin{aligned}
J\left(D_{\mathrm{CaCO}_{3}}\right)= & \underbrace{k_{\mathrm{CaCO}_{3}}^{\mathrm{form}} \cdot \mu_{P}^{\max }(T, I) \cdot \gamma\left(\mathrm{NO}_{3}^{-}, \mathrm{NH}_{4}^{+}\right) \cdot P \cdot r_{\mathrm{C}: \mathrm{N}}}_{\mathrm{CaCO}_{3} \text { formation }} \\
& -\underbrace{k_{\mathrm{CaCO}_{3}}^{\text {diss }} D_{\mathrm{CaCO}_{3}}}_{\text {dissolution }} .
\end{aligned}
$$

$\mathrm{CaCO}_{3}$ increases by $0.07 \mathrm{~mol}\left(k_{\mathrm{CaCO}_{3}}^{\text {form }}\right)$ for each mole of organic carbon produced by net primary production and it dissolves at a fixed rate of $0.0057 \mathrm{day}^{-1}\left(k_{\mathrm{CaCO}_{3}}^{\text {diss }}\right)$ in the water column and at 0.002 day $^{-1}\left(k_{S_{\mathrm{CaCO}_{3}}}^{\text {diss }}\right)$ in the sediment.

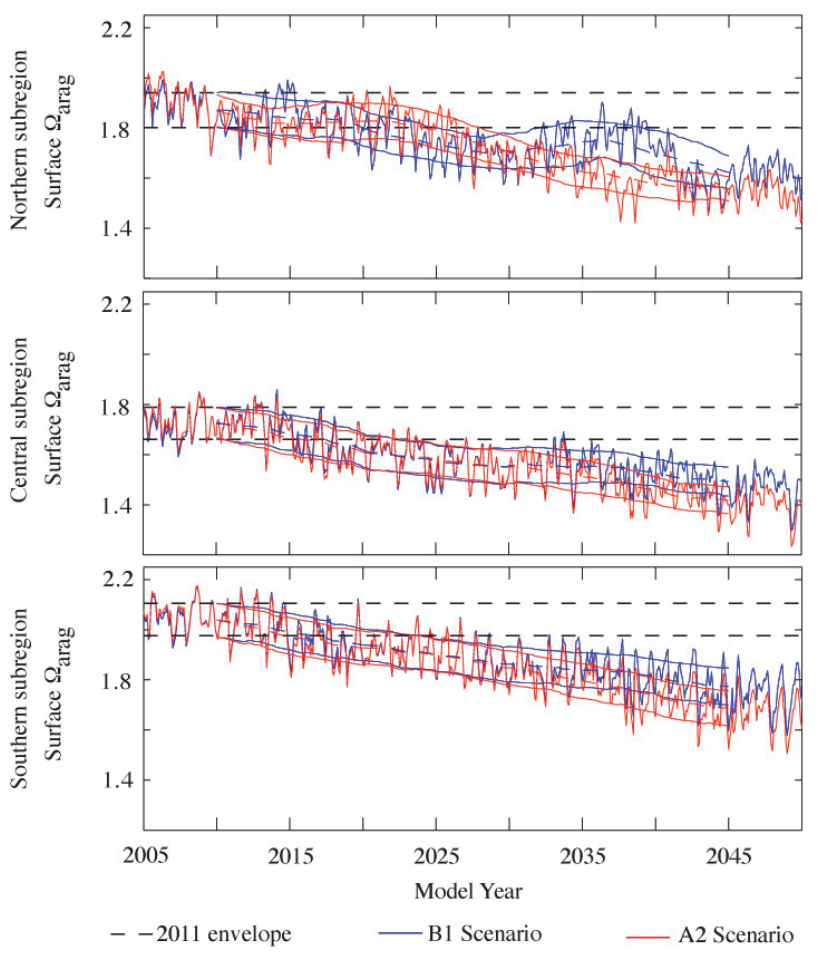

Fig. A3. Simulated time series of monthly mean surface $\Omega_{\text {arag }}$ for the two employed IPCC-SRES scenarios A2 (red) and B1 (blue), for the northern (top panel), central (center panel) and southern (bottom panel) subregions, with the 10 -yr running average (dashed red and blue lines) of the mean for all grid cells of each subregion. The area between the solid lines defines the range of annual variability or envelope (mean \pm 1 STD) of $\Omega_{\text {arag }}$ for 2011 (black, $\sim 395 \mathrm{ppm}$ atmospheric $p \mathrm{CO}_{2}$ ) and the transient simulations following the A2 (red) and B2 (blue) emissions scenarios. The results are based on simulations with the $15-\mathrm{km}$ resolution set-up.

Acknowledgements. We are grateful to Damian Loher for his support with the model simulations. We thank Thomas Frölicher, Fortunat Joos and Marco Steinacher who kindly provided us with results from their NCAR CSM 1.4-carbon model simulations. We would also like to thank Simone Alin and Katherine Harris for the observational data and Kay Steinkamp, Mark Payne and Diego Santaren for beneficial discussions and statistical support. C. H. was supported by the European Project of Ocean Acidification (EPOCA), which received funding from the European Community's Seventh Framework Programme (FP7/2007-2013) under grant agreement no. 211384. EPOCA is endorsed by the international programs Integrated Marine Biogeochemistry and Ecosystem Research (IMBER), Land-Ocean Interactions in the Coastal Zone (LOICZ), and Surface Ocean Lower Atmosphere Study (SOLAS). C. H., M. V., Z. L., A. M. P. M. and N. G. also acknowledge support by ETH Zurich. S. D. acknowledges support from NASA-NNX11AF55G.

Edited by: L. Cotrim da Cunha 


\section{References}

Alin, S. R., Feely, R. A., Dickson, A. G., Hernandez-Ayon, J. M., Juranek, L. W., Ohman, M. D., and Goericke, R.: Robust empirical relationships for estimating the carbonate system in the Southern California Current System and application to CalCOFI hydrographic cruise data (2005-2011), J. Geophys. Res., 117, C05033, doi:10.1029/2011JC007511, 2012.

Barnier, B., Siefridt, L., and Marchesiello, P.: Thermal forcing for a global ocean circulation model using a three-year climatology of ECMWF analyses, J. Mar. Syst., 6, 363-380, doi:10.1016/0924-7963(94)00034-9, 1995.

Blackford, J. and Gilbert, F.: $\mathrm{pH}$ variability and $\mathrm{CO}_{2}$ induced acidfication in the North Sea, J. Mar. Syst., 64, 229-241, doi:10.1016/j.jmarsys.2006.03.016, 2007.

Bograd, S. J., Castro, C. G., Di Lorenzo, E., Palacios, D. M., Bailey, H., Gilly, W., and Chavez, F. P.: Oxygen declines and the shoaling of the hypoxic boundary in the California Current, Geophys. Res. Lett., 35, L12607, doi:10.1029/2008GL034185, 2008.

Capet, X., Marchesiello, P., and McWilliams, J.: Upwelling response to coastal wind profiles, Geophys. Res. Lett., 31, L13311, doi:10.1029/2004GL020123, 2004.

Cooley, S. R., Lucey, N., Kite-Powell, H., and Doney, S. C.: Nutrition and income from molluscs today imply vulnerability to ocean acidification tomorrow, Fish Fish., 13, 182-215, doi:10.1111/j.1467-2979.2011.00424.x, 2012.

da Silva, A., Young, C., and Levitus, S.: Atlas of surface marine data 1994, Tech. Rep. Volume 1: Algorithms and procedures. Technical Report NOAA Atlas NESDIS 6, National Oceanic and Atmospheric Administration, Washington, DC, 1994.

Dickson, A. G.: An exact definition of total alkalinity and a procedure for the estimation of alkalinity and total inorganic carbon from titration data, Deep-Sea Res., 28, 609-623, doi:10.1016/0198-0149(81)90121-7, 1981.

Dickson, A. G.: Thermodynamics of the dissociation of boric acid in synthetic seawater from 273.15 to $318.15 \mathrm{~K}$, Deep-Sea Res., 37, 755-766, doi:10.1016/0198-0149(90)90004-F, 1990.

Dickson, A. G. and Millero, F. J.: A comparison of the equilibrium constants for the dissociation of carbonic acid in seawater media, Deep-Sea Res., 34, 1733-1743, doi:10.1016/01980149(87)90021-5, 1987.

Doney, S. C., Fabry, V. J., Feely, R. A., and Kleypas, J. A.: Ocean acidification: The other $\mathrm{CO}_{2}$ problem, Annu. Rev. Mar. Sci., 1, 169-192, doi:10.1146/annurev.marine.010908.163834, 2009.

Doney, S. C., Ruckelshaus, M., Duffy, J. E., Barry, J. P., Chan, F., English, C. A., Galindo, H. M., Grebmeier, J. M., Hollowed, A. B., Knowlton, N., Polovina, J., Rabalais, N. N., Sydeman, W. J., and Talley, L. D.: Climate change impacts on marine ecosystems, Annu. Rev. Mar. Sci., 4, 11-37, doi:10.1146/annurev-marine-041911-111611, 2012.

Dorman, C. E. and Winant, C. D.: Buoy observations of the atmosphere along the west coast of the United States, 1981-1990, J. Geophys. Res., 100, 16029-16044, doi:10.1029/95JC00964, 1995.

Feely, R. A., Sabine, C. L., Lee, K., Berelson, W., Kleypas, J., Fabry, V. J., and Millero, F. J.: Impact of anthropogenic $\mathrm{CO}_{2}$ on the $\mathrm{CaCO}_{3}$ system in the oceans, Science, 305, 362-366, doi:10.1126/science.1097329, 2004.

Feely, R. A., Sabine, C. L., Hernandez-Ayon, J. M., Ianson, D., and Hales, B.: Evidence for upwelling of corrosive "acidi- fied" water onto the continental shelf, Science, 320, 1490-1492, doi:10.1126/science.1155676, 2008.

Friedrich, T., Timmermann, A., Abe-Ouchi, A., Bates, N. R., Chikamoto, M. O., Church, M. J., Dore, J. E., Gledhill, D. K., Gonzalez-Davila, M., Heinemann, M., Ilyina, T., Jungclaus, J. H., McLeod, E., Mouchet, A., and SantanaCasiano, J. M.: Detecting regional anthropogenic trends in ocean acidification against natural variability, Nat. Clim. Change, 2, 167-171, doi:10.1038/nclimate1372, 2012.

Frölicher, T., Joos, F., Plattner, G., Steinacher, M., and Doney, S.: Natural variability and anthropogenic trends in oceanic oxygen in a coupled carbon cycle-climate model ensemble, Global Biogeochem. Cy., 23, GB1003, doi:10.1029/2008GB003316, 2009.

García-Reyes, M. and Largier, J.: Observations of increased winddriven coastal upwelling off central California, J. Geophys. Res., 115, C04011, doi:10.1029/2009JC005576, 2010.

Glover, D., Jenkins, W., and Doney, S.: Modeling Methods for Marine Science, Cambridge University Press, Cambridge, UK and New York, NY, USA, 996 pp., 2011.

Gruber, N.: Warming up, turning sour, losing breath: Ocean biogeochemistry under global change, Philos. T. R. Soc. A, 369, 1980-1996, doi:10.1098/rsta.2011.0003, 2011.

Gruber, N., Frenzel, H., Doney, S. C., Marchesiello, P., McWilliams, J. C., Moisan, J. R., Oram, J. J., Plattner, G.-K., and Stolzenbach, K. D.: Eddy-resolving simulation of plankton ecosystem dynamics in the California Current System, Deep-Sea Res., 53, 1483-1516, doi:10.1016/j.dsr.2006.06.005, 2006.

Gruber, N., Lachkar, Z., Frenzel, H., Marchesiello, P., Munnich, M., McWilliams, J., Nagai, T., and Plattner, G.-K.: Eddy-induced reduction of biological production in Eastern Boundary Upwelling Systems, Nat. Geosci., 4, 787-792, doi:10.1038/ngeo1273, 2011.

Gruber, N., Hauri, C., Lachkar, Z., Loher, D., Frölicher, T. L., and Plattner, G.-K.: Rapid progression of ocean acidification in the California Current System, Science, 337, 220-223, doi:10.1126/science.1216773, 2012.

Hales, B., Takahashi, T., and Bandstra, L.: Atmospheric $\mathrm{CO}_{2}$ uptake by a coastal upwelling system, Global Biogeochem. Cy., 19, GB1009, doi:10.1029/2004GB002295, 2005.

Harris, K., DeGrandpre, M., and Hales, B.: Aragonite saturation states in a coastal upwelling zone, in review, 2013.

Hauri, C., Gruber, N., Plattner, G.-K., Alin, S., Feely, R. A., Hales, B., and Wheeler, P. A.: Ocean acidification in the California Current System, Oceanography, 22, 58-69, doi:10.5670/oceanog.2009.97, 2009.

Hinga, K. R.: Effects of $\mathrm{pH}$ on coastal marine phytoplankton, Mar. Ecol.-Prog. Ser., 238, 281-300, doi:10.3354/meps238281, 2002.

Iglesias-Rodriguez, M. D., Halloran, P. R., Rickaby, R. E. M., Hall, I. R., Colmenero-Hidalgo, E., Gittins, J. R., Green, D. R. H., Tyrrell, T., Gibbs, S. J., von Dassow, P., Rehm, E., Armbrust, E. V., and Boessenkool, K. P.,: Phytoplankton calcification in a high- $\mathrm{CO}_{2}$ world, Science, 320, 336-340, doi:10.1126/science.1154122, 2008.

Ilyina, T., Zeebe, R. E., Maier-Reimer, E., and Heinze, C.: Early detection of ocean acidification effects on marine calcification, Global Biogeochem. Cy., 23, GB1008, doi:10.1029/2008GB003278, 2009.

Jin, X., Gruber, N., Dunne, J. P., Sarmiento, J. L., and Armstrong, R. A: Diagnosing the contribution of phytoplankton functional groups to the production and export of particulate 
organic carbon, $\mathrm{CaCO}_{3}$, and opal from global nutrient and alkalinity distributions, Global Biogeochem. Cy., 20, GB2015, doi:10.1029/2005GB002532, 2006.

Juranek, L. W., Feely, R. A., Peterson, W. T., Alin, S. R., Hales, B., Lee, K., Sabine, C. L., and Peterson, J.: A novel method for determination of aragonite saturation state on the continental shelf of central Oregon using multi-parameter relationships with hydrographic data, Geophys. Res. Lett., 36, L24601, doi:10.1029/2009GL040778, 2009.

Key, R., Kozyr, A., Sabine, C., Lee, K., Wanninkhof, R., Bullister, J., Feely, R., Millero, F., Mordy, C., and Peng, T.-H.: A global ocean carbon climatology: Results from Global Data Analysis Project (GLODAP), Global Biogeochem. Cy., 18, GB4031, doi:10.1029/2004GB002247, 2004.

King, J. R., Agostini, V. N., Harvey, C. J., McFarlane, G. A., Foreman, M. G. G., Overland, J. E., Di Lorenzo, E., Bond, N. A., and Aydin, K. Y.: Climate forcing and the California Current ecosystem, ICES J. Mar. Sci., 68, 1199-1216, doi:10.1093/icesjms/fsr009, 2011.

Kleypas, J., Feely, R., Fabry, V., Langdon, C., Sabine, C., and Robbin, L.: Impacts of Ocean Acidification on Coral Reefs and Other Marine Calcifiers: A Guide for Future Research, Report of a workshop held 18-20 April 2005, St. Petersburg, FL, sponsored by NSF, NOAA, and the US Geological Survey, 88 pp., 2006.

Lachkar, Z. and Gruber, N.: What controls biological production in coastal upwelling systems? Insights from a comparative modeling study, Biogeosciences, 8, 2961-2976, doi:10.5194/bg-82961-2011, 2011.

Langer, G., Geisen, M., Baumann, K. H., Klaes, J., Riebesell, U., Thoms, S., and Young, J. R.: Species-specific responses of calcifying algae to changing seawater carbonate chemistry, Geochem. Geophys. Geosyst., 7, Q09006, doi:10.1029/2005GC001227, 2006.

Lee, K., Tong, L., Millero, F., Sabine, C., Dickson, A., Goyet, C., Geun-Ha, P., Wanninkhof, R., Feely, R., and Key, R.: Global relationships of total alkalinity with salinity and temperature in surface waters of the world's oceans, Geophys. Res. Lett., 33, L19605, doi:10.1029/2006GL027207, 2006.

Leinweber, A. and Gruber, N.: Variability and trends of ocean acidification in the Southern California Current System: A timeseries from Santa Monica Bay, in review, 2013.

Leinweber, A., Gruber, N., Frenzel, H., Friedrichs, G. E., and Chavez, F.: Diurnal carbon cycling in the surface ocean and lower atmosphere of Santa Monica Bay, California, J. Geophys. Res., 36, L08601, doi:10.1029/2008GL037018, 2009.

Marchesiello, P., McWilliams, J., and Shchepetkin, A.: Equilibrium structure and dynamics of the California Current System, J. Phys. Oceanogr., 33, 753-783, doi:10.1175/15200485(2003)33<753:ESADOT>2.0.CO;2, 2003.

Martin, S. and Gattuso, J.-P.: Response of Mediterranean coralline algae to ocean acidification and elevated temperature, Glob. Change Biol., 15, 2089-2100, doi:10.1111/j.13652486.2009.01874.x, 2009.

McClatchie, S., Goericke, R., Cosgrove, R., Auad, G., and Vetter, R.: Oxygen in the Southern California Bight: Multidecadal trends and implications for demersal fisheries, Geophys. Res. Lett., 37, L19602, doi:10.1029/2010GL044497, 2010.

McNeil, B. I. and Matear, R. J.: Southern Ocean acidification: A tipping point at $450 \mathrm{ppm}$ atmospheric $\mathrm{CO}_{2}$, P. Natl. Acad. Sci.
USA, 105, 18860-18864, doi:10.1073/pnas.0806318105, 2008.

Mehrbach, C., Culberson, C., and Hawley, J.: Measurement of the apparent dissociation constants of carbonic acid in seawater at atmospheric pressure, Limnol. Oceanogr., 18, 897-907, 1973.

Millero, F. J.: Thermodynamics of the carbon-dioxide system in the oceans, Geochim. Cosmochim. Ac., 59, 661-677, doi:10.1016/0016-7037(94)00354-O, 1995.

Mucci, A.: The solubility of calcite and aragonite in seawater at various salinities, temperatures, and one atmosphere total pressure, Am. J. Sci., 283, 780-799, doi:10.2475/ajs.283.7.780, 1983.

Nakićenović, N. and Swart, R.: Special Report on Emissions Scenarios: A Special Report of Working Group III of the Intergovermental Panel on Climate Change, Cambridge Univ. Press, Cambridge, UK, 20 pp., 2000.

Nam, S., Kim, H.-J., and Send, U.: Amplification of hypoxic and acidic events by La Niña conditions on the continental shelf off California, Geophys. Res. Lett., 38, L22602, doi:10.1029/2011GL049549, 2011.

Orr, J. C., Fabry, V. J., Aumont, O., Bopp, L., Doney, S. C., Feely, R. A., Gnanadesikan, A., Gruber, N., Ishida, A., Joos, F., Key, R. M., Lindsay, K., Maier-Reimer, E., Matear, R., Monfray, P., Mouchet, A., Najjar, R. G., Plattner, G.-K., Rodgers, K. B., Sabine, C. L., Sarmiento, J. L., Schlitzer, R., Slater, R. D., Totterdell, I. J., Weirig, M.-F., Yamanaka, Y., and Yool, A.: Anthropogenic ocean acidification over the twentyfirst century and its impact on calcifying organisms, Nature, 437, 681-686, doi:10.1038/nature04095, 2005.

Redfield, A. C., Ketchum, B. H., and Richards, F. A.: The influence of organisms on the composition of seawater, in: The Sea, vol. 2, edited by: Hill, M. N., Wiley Interscience, New York, 26-77, 1963.

Riebesell, U., Zondervan, I., Rost, B., Tortell, P. D., Zeebe, R. E., and Morel, F. M.,: Reduced calcification of marine plankton in response to increased atmospheric $\mathrm{CO}_{2}$, Nature, 6802, 264-267, doi:10.1038/35030078, 2000.

Risien, C. and Chelton, D.: A global climatology of surface wind and wind stress fields from eight years of QuickSCAT scatterometer data, J. Phys. Oceanogr., 38, 2379-2413, doi:10.1175/2008JPO3881.1, 2008.

Sabine, C. L., Feely, R. A., Gruber, N., Key, R. M., Lee, K., Bullister, J. L., Wanninkhof, R., Wong, C. S., Wallace, D. W. R., Tilbrook, B., Millero, F. J., Peng, T.-H., Kozyr, A., Ono, T., and Rios, A. F.: The oceanic sink for anthropogenic $\mathrm{CO}_{2}$, Science, 305, 367-371, doi:10.1126/science.1097403, 2004.

Sarmiento, J. L., Dunne, J., Gnanadesikan, A., Key, R. M., Matsumoto, K., and Slater, R.: A new estimate of the $\mathrm{CaCO}_{3}$ to organic carbon export ratio, Global Biogeochem. Cy., 16, 1107, doi:10.1029/2002GB001919, 2002.

Shchepetkin, A. and McWilliams, J.: The Regional Oceanic Modeling System (ROMS): a split-explicit, free-surface, topographyfollowing-coordinate oceanic model, Ocean Model., 9, 347-404, doi:10.1016/j.bbr.2011.03.031, 2005.

Steinacher, M., Joos, F., Frölicher, T. L., Plattner, G.-K., and Doney, S. C.: Imminent ocean acidification in the Arctic projected with the NCAR global coupled carbon cycle-climate model, Biogeosciences, 6, 515-533, doi:10.5194/bg-6-515-2009, 2009.

Stramma, L., Johnson, G., Sprintall, J., and Mohrholz, V.: Expanding oxygen-minimum zones in the tropical oceans, Science, 320, 655-658, doi:10.1126/science.1153847, 2008. 
Stramma, L., Schmidtko, S., Levin, L., and Johnson, G.: Ocean oxygen minima expansions and their biological impacts, Deep-Sea Res., 57, 587-595, doi:10.1016/j.dsr.2010.01.005, 2010.

Takahashi, T., Sutherland, S., Feely, R., and Wanninkhof, R.: Decadal change of the surface water $p \mathrm{CO}_{2}$ in the North Pacific: a synthesis of 35 years of observations, J. Geophys. Res., 111, C07S05, doi:10.1029/2005JC003074, 2006.
Taylor, K. E.: Summarizing multiple aspects of model performance in a single diagram, J. Geophys. Res., 106, 1934-8592, doi:10.1029/2000JD900719, 2001.

Wanninkhof, R.: Relationship between wind speed and gas exchange over the ocean, J. Geophys. Res., 97, 7373-7382, doi:10.1029/92JC00188, 1992. 